\title{
El aquitano como lengua céltica (o vascones en Aquitania)
} Joan C. Vidal

\section{Citer ce document / Cite this document :}

Vidal Joan C. El aquitano como lengua céltica (o vascones en Aquitania). In: Nouvelle revue d'onomastique, $n^{\circ} 54,2012$. pp. 129-175;

doi : https://doi.org/10.3406/onoma.2012.1753

https://www.persee.fr/doc/onoma_0755-7752_2012_num_54_1_1753

Fichier pdf généré le 04/04/2018 


\section{Joan C. Vidal \\ Barcelona}

\section{El aquitano como lengua céltica (o vascones en Aquitania)}

\section{Introducción}

Por lo común, se considera la lengua aquitana como una lengua íntimamente relacionada con el vasco actual hasta el punto de haberse pensado que fue su predecesora. Esta creencia se basa en tres firmes pilares: la constatación de Julio César y Estrabón sobre que los aquitanos diferían por su lengua del resto de galos, en un supuesto efecto de substrato pre-indoeuropeo sobre el dialecto gascón, así como la presencia en territorio gascón de antiguos nombres de personas y dioses de interpretación eusquérica. ${ }^{1}$ Ahora bien, los fundamentos de estos pilares no resulta nada seguro tal como se expondrá detalladamente en las páginas siguientes; el hecho de diferir los aquitanos de los galos no convierte necesariamente a los aquitanos en gentes no célticas, del mismo modo que los britones tampoco dejaban de ser célticos por no ser galos. Sobre los efectos de substrato, tanto pueden ser atribuidos a lenguas pre-indoeuropeas como a lenguas célticas, si bien debe darse por seguro un efecto de adstrato de tipo vascón. En cuanto a la onomástica prerromana, esta presenta tres capas posibles: una gala, otra celta no gala, y una tercera vascona, siendo precisamente esta última capa la que lleva a la confusión de hacer pasar el antiguo aquitano como lengua no-indoeuropea emparentada con el vasco. Esto último se demostrará erróneo ya que el onomástico no-indoeuropeo que se halla en la actual Gascuña se da principalmente en áreas y ciudades pobladas por vascones, hecho que hasta ahora no había sido tomado en cuenta a la hora de evaluar la situación lingüística y étnica de la región en el pasado.

\section{Exposición de la problemática}

\section{Primera noticia sobre vascones en Aquitania}

El mayor problema que surge a la hora de evaluar o reconocer nombres indígenas como propiamente aquitanos (y por consiguiente el tipo de relación que tenía la lengua aquitana con el vasco), proviene del hecho de que hasta ahora no se ha tenido en cuenta en lingüística la presencia de vascones y celtíberos en territorio aquitanorromano, lo que automáticamente desvirtuaría cualquier intento de análisis sobre la lengua aquitana en caso de no tenerse en cuenta precisamente este hecho.

La base del problema está en que la zona de mayor densidad epigráfica con antropónimos y teónimos indígenas se sitúe en el antiguo condado de Comminges (con

1 Será Luchaire ya en 1876 quien exponga científicamente la supuesta relación existente entre el antiguo aquitano y el actual vasco en base al texto juliano y a la onomástica aquitana y gascona.

Joan C. VIDAL, «El aquitano como lengua céltica (o vascones en Aquitania) ». Nouvelle Revue d'Onomastique, $\mathrm{n}^{\circ}$ 54, 2012, p. 129-176 


\section{Nouvelle Revue d'Onomastique $n^{\circ} 54-2012$}

más del doble que el resto de Aquitania), cuya antigua capital comarcal, si aceptamos lo relatado por San Isidoro (560-636), debió de poblarse con vascones trasladados allá por Pompeyo tras vencer este la rebelión sertoriana (Etimologías IX, 2, 107):

Galli autem Senones antiquitus Xenones dicebantur, quod Liberum hospitio recepissent; postea $\mathrm{X}$ in S litteram commutata est. Vacca oppidum fuit iuxta Pyrenaeum, a quo sunt cognominati Vaccei, de quibus creditur dixisse poeta 'Lateque vagantes Vaccei'. Hi Pyrenaei iugis peramplam montis habitant solitudinem. Idem et Vascones, quasi Vaccones, $\mathrm{C}$ in $\mathrm{S}$ litteram demutata, quos Gnaeus Pompeius edomita Hispania et ad triumphum venire festinans de Pyrenaei iugis deposuit et in unum oppidum congregavit unde et Converanum urbs nomen accepit.

De este texto se pueden extraer varias informaciones; por una parte, que San Isidoro es el único autor que menciona una ciudad llamada Vacca en los Pirineos (había en todo caso un río $\mathrm{Vacca}$, pero en Lusitania), cuando las ciudades antiguas que conocemos en los Pirineos son pocas pero con suficiente constancia como para creer que en realidad se refirió a la Iacca vascona (actual Jaca), por lo cual, se puede pensar que San Isidoro basó su entrada en una copia de un escrito donde se daba pie a leerlo así, o bien usó una mala copia conteniendo este error (un error que pudo estar también en el origen de otro error en el Anónimo de Rávena, donde Jaca aparece como Pacca); luego ya sería en todo caso falta del mismo San Isidoro pretender un cambio de letras inexistente en su fuente original (vascones < vaccones), para así justificar la presencia de los vascones en Iacca tal como afirma por ejemplo Tolomeo cuando la cita como una de las ciudades que poseía esta tribu; el fallo pues, parece ser que si bien San Isidoro leyó un pasaje sobre los vascones en los Pirineos, y sobre cómo estos fueron llevados por Pompeyo hacia la antigua capital de la comarca gascona de Comminges, este quiso pensar tras comprobar que muchas tribus antiguas derivaron sus tribónimos de su capital (Ausa $>$ Ausetani, Basta $>$ Bastetani, Lactora $>$ Lactorates, etc.), que los vascones debieron ser los mismos que los vacceos ya que en el territorio vascón estaría la errónea $\mathrm{Vacca}$, por lo que tal vez San Isidoro pretendió aplicar a los vascones esta misma regla, tal vez con imaginación, tal vez con alguna ayuda de una mala copia, pero apoyándose en su peculiar visión sobre la evolución de los fonemas («Senones antiquitus Xenones dicebantur»); ahora bien, por el mismo procedimiento de forzar la coincidencia de la supuesta capital tribal con el tribónimo, y tras leer mal a Salustio (Hist. II, 132), San Isidoro pudo confundir la posición geográfica de los vacceos situándolos en los Pirineos, por lo que el cambio habría sido corregir un falso error en la Iacca de Ptolomeo transformándola entonces en Vacca. En cualquier caso, la desconocida fuente que usó San Isidoro y que trataba sobre una fundación pompeyana de Lugdunum Convenarum debió ser usada también por San Jerónimo (340-420) en una carta que dirigió «Contra Vigilancio» según se desprende del texto subrayado por ser idéntico al que más tarde usará San Isidoro:

Nimirum respondet generi suo, ut qui de latronum et convenarum natus est semine quos Cn. Pompeius edomita Hispania, et ad triumphum redire festinans, de Pyrenaei jugis deposuit, et in unum oppidum congregavit: unde et Convenarum urbs nomen accepit. Hucusque latrocinetur contra Ecclesiam Dei et de Vectonibus [en otras versiones es 'Vasconibus'], 


\section{El aquitano como lengua céltica (o vascones en Aquitania)}

Arrebacis, Celtiberisque descendens, incurset Galliarum Ecclesias, portetque nequaquam vexillum crucis, sed insigne diaboli.

Ciertamente él representa a su raza: surgida de una caterva de bandoleros y gentes traídas desde todos los rincones, concretamente aquellos a los que Cneo Pompeyo, después de conquistar toda Hispania y apresurarse en regresar después de sus triunfos, hizo bajar de los Pirineos reuniéndolos a todos en una ciudad, debiendo la ciudad de los convenae su nombre a este hecho [*Convena procede de «convenio, de reunir»]; pues él [Vigilancio] ha llevado con su turba iguales ataques sobre la Iglesia de Dios, y tal como sus ancestros vectones, arrebaces [arevacos] y celtíberos, él asalta las iglesias de la Galia, no con el estandarte de la cruz, sino al contrario, con el emblema del diablo.

De hecho, el pasaje de San Jerónimo es contradictorio ya que los arévacos eran celtíberos, por lo que la distinción entre arevacos y celtíberos que hace resulta artificiosa y da lugar a pensar que es producto de una confusión en las fuentes, o por proceder de una mala copia o transmisión (se dan casos como que los lakketanoi pasen a iakketanoi, que los vettones pasen a ser veptones, o que los mismos vascones de Salustio pasen a ser confundidos por vacceos en la «Vida de Sertorio»). Como se ve, tanto San Jerónimo como San Isidoro usaron una misma frase, posibilitando eso sospechar que esta fuese copiada desde una fuente hoy en día ignota, acaso tal vez desde alguno de los fragmentos actualmente perdidos del historiador Salustio (existe ciertamente una gran semejanza con el fragmento 375 del tercer libro de sus Historias: «[Pompeius], devictis Hispanis, trophaea in Pyrenaeis iugis constituit»), siendo la misma fuente usada seguramente también por Plinio para informarse, ya que tras enumerar todas las tribus aquitanas dice que «después están los convenae reunidos en una civitas» (H.N., IV, 108); y lo mismo se podría decir sobre la mención que hace Estrabón de los convenae su libro IV $(2,1)$. En todo caso, esta frase se aplicaría mejor según el momento histórico en que sucede la acción con un sentido de rendición y consiguiente recolocación de los últimos reductos sertorianos (fundamentalmente tres ciudades arevacas, la Calagurris celtíbera, la Osca ilérgete, y seguramente, los destacamentos dispuestos en los Pirineos para defender sus pasos), siendo problemática la inclusión de los vascones en esa misma recolocación por desconocerse si fueron colocados de grato como recompensa en caso de haber actuado como aliados de Pompeyo, o si fueron forzados a ello en el caso de haber servido para Sertorio.

Así pues, el testimonio de San Jerónimo (que tuvo acceso tanto a archivos históricos como religiosos), el mismo etnónimo de conveniano («los que han confluido», relacionable con conventum «pacto hecho entre personas reunidas» y convenire «reunirse», de donde procede el castellano «convenir»), más las evidencias toponímicas que más adelante se tratarán, confirman con bastante base que la comarca del Comminges fue colonizada por vascones e hispanoceltas, y lo mejor del caso, es que este hecho histórico puede ser enlazado con otras noticias históricas de la misma época sobre los mismos vascones y su propia área de asentamiento, así como a ciertos pasajes como el que hace referencia a un reordenamiento del territorio según Plutarco (Vida de Pompeyo, en Vidas Paralelas): «...[Pompeyo] permaneció en Hispania lo suficiente como para sofocar grandes desórdenes y recomponer todo el gobierno, ya que todo parecía seguir 


\section{Nouvelle Revue d'Onomastique n $54-2012$}

\section{en un estado inflamatorio.»}

Ciertamente, Pompeyo usó sabiamente sus dotes diplomáticas para solventar las tensiones hispanas, hecho que nos confirma Cicerón (In Verrem, V, 58), donde se puede observar que los que sobrevivieron a la derrota sertoriana de Perpenna encontraron amnistía en Pompeyo:

Después de que Perpenna fuese muerto, muchos de los soldados sertorianos buscaron refugio en Pompeyo, este hombre ilustrado y gentil. ¿Acaso hubo alguno de entre ellos al que no preservase salvo y sano con la mayor gentileza? ¿Hubo algún ciudadano suplicante que no estrechase esa mano justa e invencible como compromiso de confianza y como garantía de una segura salvedad?

Es bastante posible que muchos de estos soldados y oficiales amnistiados fueran el objeto de la «recolocación» o deportación pirenaica de Pompeyo, lo que habilitaría rebajar la tensión en Hispania por una parte, mientras que por la otra se aseguraría una región estratégica con importantes pasos pirenaicos y que limitaba además con los aquitanos independientes.

A todo esto, se podría objetar que mientras que el enciclopedista únicamente menciona a los vascones como actores de esa migración, San Jerónimo no dice nada de ellos y sólo hace mención en su carta a hispanoceltas (vetones, arevacos y celtíberos), lo que da pie a pensar que alguno de los dos pudo confundir las tribus implicadas en la migración norpirenaica. Esto no representa ninguna dificultad, ya que mientras San Isidoro sólo menciona a los vascones porque trata únicamente de ellos y lo que únicamente pretendía era introducir su marco geográfico e histórico, San Jerónimo habla más extensamente sobre gentes "traidas desde todos los rincones», lo que es evidente cuando el santo menciona luego a los vetones de la Lusitania, dando así una idea de la magnitud que tuvo la operación emprendida por Pompeyo, y que es contradictoria con hacer «bajar de los Pirineos» a los sertorianos que aún quedarían por someter tras la muerte de Perpenna, ya que bajarlos de los Pirineos no es tanto como traerlos de todos los rincones. De hecho, la referencia que hace San Jerónimo sobre celtíberos, vetones y arevacos, es cuando habla de los orígenes del herisarca (no hay que olvidar que San Jerónimo vivió con Vigilancio en Tierra Santa y debió conocerle bastante bien), lo que no implica necesariamente que todos los convenae debieran tener (sólo) esos orígenes; así, por poner un ejemplo, tenemos poblaciones sudamericanas que mantienen el habla véneta o alemana a causa de una mayor concentración de colonos de un mismo origen llegados al continente en el siglo XIX, siendo además esta tendencia muy natural cuando se dan colonizaciones multiétnicas, ya que las etnias tienden a concentrarse a razón de que el tener un origen común facilita la cooperación interpersonal (otro caso semejante es el de los colonos europeos de la Algeria francesa o pied-noirs, estos solían crear barrios y pueblos de mallorquines, valencianos, provenzales, etc.).

Igualmente, se debe tener en cuenta que si el último reducto multiétnico sertoriano se refugió en los valles pirenaicos, y que es muy posible además que los mismos jacetanos estuvieran implicados en las guerras sertorianas, el que Pompeyo hiciera «bajar de los Pirineos» a los rebeldes que aún quedaban en ese reducto montañoso pudo vincular 


\section{El aquitano como lengua céltica (o vascones en Aquitania)}

la inclusión de gentes locales de estirpe ibérica en la fundación de la nueva tribu conveniana; es más, si se reconoce que incluso habían vetones defendiendo el último reducto sertoriano, tampoco se puede descartar que miembros de tribus ibéricas que participaron en el bando sertoriano fueran igualmente forzados a establecerse en el Comminges; en definitiva, resultaría muy arriesgado considerar que todos los antropónimos y teónimos no romanos hallados en la epigrafía romana del Comminges correspondan a la situación lingüística y cultural prerromana de la región, y por extensión, al resto de Aquitania.

\section{La causa: las alianzas de los vascones}

Las tribus implicadas en la narración de San Isidoro son fáciles de situar: los vetones ocupaban las zonas montañosas de Ávila, Salamanca y Cáceres, los vacceos ocupaban las comarcas llanas de la actual Castilla-y-León, los arevacos (nombre que significaría «vacceos orientales» o sería gentilicio de los que vivían entorno al río Areva tal como cuenta Plinio) ocupaban la cuenca superior del Duero, fundamentalmente Soria, Segovia y el sur burgalés, los celtíberos estaban asentados a lo largo del Sistema Ibérico, dominando por lo tanto las zonas montañosas de Soria, Zaragoza, Teruel, Guadalajara y Cuenca, y en cuanto a los vascones, estos ocupaban la actual Navarra y parte de Guipúzcoa (más tarde ocuparán también las comarcas aragonesas de Cinco Villas y Jacetania, y tal vez es posible que ocupasen también el Sobrarbe, la Ribagorza y el Pallars ya que el mismo Plinio en su Historia Naturalis -III,3- nos dice que los ceretanos lindaban con los vascones).

La implicación exacta de los vascones en la guerra sertoriana es desconocida, y se proponen teorías que van desde favorecer una alianza con Sertorio hasta otras que apuntan a una alianza con Pompeyo. En todo caso, es a principios del siglo I a.C. cuando el general Sertorio (que estaba refugiado en la Mauretania), es requerido por los lusitanos por motivo de su destreza en temas militares tanto para ayudarles a combatir otras tribus, como para deshacerse de sus gobernadores romanos puesto que estos estaban incurriendo en graves abusos fiscales y morales sobre toda la población indígena. Su inmediato éxito con los lusitanos provocó que otras tribus hispanas se aliaran con él para así rechazar el dominio romano, creando este una milicia profesionalizada que usaba igualmente tácticas indígenas de guerrilla. Esta guerra fue lógicamente registrada por los historiadores romanos, y es así que sabemos por fragmentos de Salustio que los layetanos y los indígetes eran sertorianos ya que Pompeyo arrasó sus costas; por Floro (Epítome, II, X, III, 2) sabemos que los celtíberos también eran sertorianos, lo mismo que los ilérgetes de Osca y los Edetanos de Valentia y Sucro; también sabemos que los arevacos apoyaron a Sertorio ya que acabaron por rendir a Pompeyo sus ciudades (Termes, Uxama, Segovia), y sabemos igualmente por Apiano (Guerras Civiles, I, 13,112) que los vacceos también se aliaron con Sertorio puesto que Pompeyo tuvo que atacar una de sus principales ciudades, Pallantia (actual Palencia). También se podría suponer que parte de los vascones se aliaron con Sertorio, ya que fue Calagurris (Calahorra) la ciudad que más sufrió la guerra según Floro, hasta el punto de obligar a Sertorio a desplazarse hasta allí para salvarla del asedio pompeyano, lo que provocó la muerte de 3000 soldados romanos 


\section{Nouvelle Revue d'Onomastique n $54-2012$}

según Apiano (G.C. I, 13, 112), pero no parece que esa ciudad tuviese un componente étnico vascón por aquel entonces según varios indicios tratados por diversos autores. De todas formas, un posible indicio de la intervención de los vascones en las guerras sertorianas resultaría tras interpretar un pasaje de Plutarco (Vida de Sertorio): "[...] ya que todas las tribus del Ebro estaban unidas por su causa [la de Sertorio], reuniendo así un gran ejército de hombres procedentes de todos los confines». Este pasaje implicaría que todas las tribus situadas en el Ebro apoyaron a Sertorio: celtíberos, vascones, berones, sedetanos, ilérgetes, e ilercavones, excepto si la frase implicase únicamente a aquellas tribus bajo dominio romano. En todo caso, una colaboración activa o pasiva con la causa sertoriana por parte de los vascones estaría plenamente justificada: tras varias décadas guardando sus fronteras del amenazante expansionismo romano, la victoria de una rebelión descentralizadora supondría el fin de la amenaza de ser conquistados y sometidos por Roma (no hay que olvidar que no hacía tanto tiempo que los romanos arrasaron con la Numancia celtíbera y sometieron a los lusitanos de Viriato).

Además, teniendo en cuenta que Sertorio fundó una especie de capital civilizadora en Osca en la que pretendió instruir e ilustrar a los hijos de los caudillos tribales, es de suponer que esta ciudad estuvo suficientemente asegurada, lo que implica un control de los pasos pirenaicos (Jacetania, territorio que pasará más tarde a ser administrado por los vascones), cosa que a su vez implica dominar o tener como aliados a los jacetanos, pero sin olvidar también a los vascones, mucho más cuando Huesca dista 100 kilómetros del antiguo territorio tribal vascón. En todo caso, fuese mediante alianza, o mediante el uso de la fuerza, Sertorio ya demostró de buen principio su voluntad de asegurarse los pasos pirenaicos: «Entonces envió a Julio Salinator con 6000 soldados para cerrar los puertos del Pirineo».

Que las guerras sertorianas afectaron el Pirineo es indudable por lo que nos cuenta Estrabón precisamente sobre la comarca de Jaca:

La Jacetania es un país donde no sólo Sertorio mantuvo su lucha en su día contra Pompeyo, sino que también más tarde Sexto, el hijo de Pompeyo, luchó contra los generales del César. Más allá de la Jacetania, hacia el norte, es donde está situada la tribu de los vascones y donde está la ciudad de Pompelo, o como se puede decir, Pompeiopolis. (Geog. III, 4, 10)

Estrabón creía que los Pirineos estaban ubicados sobre un eje de norte a sur, cosa ciertamente errónea, pero deja claro que tanto para Sertorio como para Pompeyo, conseguir el control de los pasos pirenaicos era una acción estratégica. Estrabón también describió el territorio de estos jacetanos:

Su país comienza en las faldas de los Pirineos para luego extenderse hacia las llanuras que hay junto a las ciudades de Osca e Ilerda, siendo ya estas ciudades de dominio ilérgete y no demasiado lejanas del Ebro. Fue en esas dos ciudades, y en Calagurris, una ciudad de los vascones, así como en las ciudades costeras de Tarraco y Hemeroscopium, que Sertorio libró sus últimas batallas después de ser expulsado de la Celtiberia, pero fue en Osca donde halló su fin. 


\section{El aquitano como lengua céltica (o vascones en Aquitania)}

Si se acepta la alianza de los vascones con Sertorio, resultaría aparentemente contradictorio el hecho de que Pompeyo hibernase un año precisamente entre ellos, cosa que no se comprende si no hubo algún tipo de alianza o acuerdo ya que una tropa necesita ser suministrada de víveres, y por lo tanto precisa asentarse en un territorio sojuzgado o no hostil. Este hipotético cambio de bando se podría entender mejor con unas informaciones que nos brinda el mismo Plutarco (Vida de Pompeyo, en Vidas Paralelas) cuando narra como a la llegada de Pompeyo a Hispania las tropas romanas fueron revitalizadas y cómo «las tribus que no estaban firmemente aliadas a Sertorio empezaron a inquietarse y a cambiar de bando», aspecto que el mismo Plutarco nos repite otra vez cuando trata sobre la vida de Pompeyo:

Cuando Pompeyo llegó a Hispania, la reputación del nuevo general produjo los resultados habituales: transformó a los hombres de Metelo con nuevas esperanzas, y aquellas tribus que no estaban firmemente aliadas con Sertorio comenzaron a inquietarse y a cambiar de bando.

Así pues, pudieron darse varias posibilidades: que los vascones no se aliasen al principio del conflicto con ningún bando, o que se aliasen con Sertorio para después cambiar de bando, o bien que los vascones se aliasen con Sertorio para después cambiar de bando pero quedando en el bando sertoriano los teóricos guerreros vascones enviados a Sertorio (para ayudarlo en sus campañas tras jurarle fidelidad). Se explicaría por lo menos con la segunda o con la tercera posibilidad que se haya registrado un ataque sertoriano en territorio vascón según la presencia de restos arqueológicos en forma de glandes inscriptae de plomo con propaganda pro-sertoriana encontrados en el arrasado oppidum del Castillo de Irulegui (Laquidáin, Aranguren), por lo que puede sospecharse que entre los que revirtieron su alianza estuvieran efectivamente los vascones, y de ahí la reacción sertoriana.

Tenemos además que sopesar el hecho de que Pompeyo se viese obligado a ha refugiarse en un territorio no sertoriano:

Porque su versátil enemigo [Sertorio] solía cortar las comunicaciones entre ellos [Pompeyo y Metelo], mostrando una gran habilidad apareciendo en muchos lugares en un corto espacio de tiempo, y conduciéndolos de una batalla a otra. Finalmente, tras cortar sus suministros y devastar la región, y tras obtener el control del mar, empujó a ambos fuera de aquella parte de Hispania que controlaba, forzándolos a refugiarse en otras regiones por falta de provisiones. (Vida de Pompeyo)

Siendo este pasaje perfectamente vinculable con otro que aparece en la «Vida de Sertorio» escrita por el mismo Plutarco donde se narra que:

[Sertorio] avanzó sobre el enemigo con grandes refuerzos y comenzó por cortar sus suministros terrestres mediante emboscadas, moviendo flancos, y cambiando la marcha en cada dirección, mientras que usando tácticas piráticas, asediaba sus suministros marítimos; fue así que los generales romanos se vieron forzados a separarse, Metelo retornando a la Galia y Pompeyo pasando el invierno entre los vacceos. 


\section{Nouvelle Revue d'Onomastique $n^{\circ} 54-2012$}

Pasaje en el que se detecta un error, ya que si por una parte sabemos que los vacceos eran sertorianos y serán atacados por Pompeyo al año siguiente, por la otra tenemos que el historiador Salustio nos dice que Pompeyo se dirigió, o refugió, ese año realmente entre los vascones (Historias II, frag. 93M):

Seguidamente, el ejército romano se dirigió hacia el territorio de los vascones para acumular provisiones, por lo cual Sertorio también tuvo que mover su posición puesto que para él era de vital importancia mantener un acceso fácil hacia la [Galia] y Asia.

Aspecto que nos confirmaría indirectamente Apiano (Guerras Civiles I, 110) al registrar para esa misma época los movimientos de Pompeyo:

De esta manera [Pompeyo y Metelo] pasaron el verano, y otra vez se separaron dirigiéndose a sus campamentos de invierno [...] Con esta y otras fuerzas en sus manos, Metelo y Pompeyo descendieron otra vez de los Pirineos hacia el Ebro, mientras que Sertorio y Perpenna dejaban la Lusitania para encontrarse con ellos. .

Evidentemente, los vacceos no habitaban los Pirineos, y queda bien confirmada la presencia de Pompeyo entre los vascones; de hecho, tras hibernar entre los vascones, Pompeyo atacó una ciudad vaccea pro-sertoriana: Pallantia, lo que acaba por confirmar que debió haber algún error de transmisión en ese pasaje de Plutarco, seguramente ayudado por la confusión de la interacción de Pompeyo con vascones y vacceos en un mismo año... y en el anterior, ya que en Salustio (Hist. II, frag. 132) nos dice que «Rechazado [Pompeyo] de la fortaleza de Lethes se retiró hacia el país de los vacceos, y desde alli se dirigió hacia los Pirineos». En fin, es el mismo Salustio quien nos confirma, tal como hace Apiano, que Pompeyo hibernó en los Pirineos durante los dos primeros años que estuvo en Hispania: «Pompeyo se acuarteló ese invierno cerca de los Pirineos, tal como hizo el año anterior» (Hist. II, frag. 202), por lo que queda descartada cualquier teoría que pretenda hacer a los vacceos los protagonistas de un asentamiento pompeyano.

Seguramente debió ser durante esa hibernación cuando Pompeyo fundó Pamplona (Pompeiopolis para Estrabón, *Pompei-ilun para los vascones, de la que quedaría en el vasco actual únicamente la mención de «ciudadela»: Iruña $<*$ Ilun- $a$, con palatalización expresiva), hecho que queda delatado por el mismo trazado del casco viejo de la ciudad al contener la forma de un campamento romano, lo que indirectamente debilita la suposición de algunos autores sobre que Pamplona fue fundada por motivos punitivos como aconteció en otras regiones, siendo estas más bien refundaciones de ciudades preexistentes, cosa que no ocurriría con Pompaelo.

Así pues, se pueden proponer dos posibilidades lógicas: que los vascones recibieran y ayudaran a Pompeyo tras haber cambiado de bando y ser asediados por los sertorianos, o que los vascones acabasen por entrar en la guerra ayudando al bando pompeyano tras pedir algún tipo de recompensa o poner condiciones. Se entendería también que no exista ningún testimonio antiguo que relate un enfrentamiento entre los vascones y el poder oficial de Roma, además de explicar los antropónimos de vascones que portan el nombre 


\section{El aquitano como lengua céltica (o vascones en Aquitania)}

de Pompeyo, lo que parecería reflejar una admiración o un buen recuerdo por este general de parte de vascones romanizados (podría ser el caso por ejemplo de un tal Cneus Pompeius Pompaelonensis, CIL II, 4232). Igualmente, esa alianza explicaría la aparente extensión que experimentaría el territorio vascón, ya que tras la guerra se atribuyen a los vascones antiguos territorios sertorianos como la Ribera de Navarra, el Pirineo central y la comarca de las Cinco Villas, siendo por lo además bien conocida la política de recompensas que practicó Pompeyo en Asia Menor, y siendo esta una estrategia perfectamente plausible al conceder a la mayor tribu aliada en la región territorios que debían ser inmediatamente asegurados; sería esta entonces una forma indirecta de afianzar el clientelismo vascón, mientras que a la vez se debilitaría socioeconómicamente a los derrotados, además de extender consiguientemente ese mismo clientelismo a zonas sertorianas, lo que explicaría también la formación de los convenae con elementos vascones, y que estos disfrutasen del derecho romano según Estrabón (Geog. IV, 2); con estos supuestos, se entendería que no haya noticia de enfrentamientos con los vascones y que estos se integrasen culturalmente y políticamente en el orbe latino. Fuere como fuere, los vascones apoyaron en un momento dado a Pompeyo, ya que de otra manera no se entendería que este hubiera acampado e invernado en el corazón de su territorio.

\section{La región colonizada: el territorio de los convenae}

Pruebas indirectas de la presencia de gentes hispánicas podrían ser las monedas indígenas halladas en Saint-Bertrand-de-Comminges, ya que corresponden al ámbito hispano más inmediato $($ bolskan $=$ Boltaña/Boletania o Huesca $/ O s c a$, kese $=$ Tarragona, kelse $=$ Gelsa, y Iacca $=$ Jaca $)$.

Luego, en determinados epígrafes de la región, tenemos que un tal Iacessis (Valcabrère; para detalles y bibliografía de teónimos y antropónimos aquitanos consultar GORROCHATEGUI, 1984) podría estar relacionado con alguna persona cuyos orígenes estarían en la ciudad de Iacca (actual Jaca), tenemos a unos gomferani (Saint-Béat) que nos remiten a los convenae en esta población cercana al Valle de Aran (*Convena $>$ *convenani $>*$ gonfenani y disimilación de nasales), y luego ya fuera de la región hay un tal Oscitaris (Ponsan-Soubrian, Gers) que podría relacionarse con la Osca suessetanailérgete (actual Huesca) ya que el sufijo -tar sirve en vasco para indicar pertenencias (Bilbo - bilbotar, bilbaíno), si bien no se puede descartar que esté relacionado con la tribu aquitana de los oscidates. Las mismas dudas tuvo Gorrochategui respecto a si Iacessis y Oscitaris estaban formados en base a topónimos, si bien asignó una función laboral para explicar los gomferani.

Queda más patente la histórica colonización hispana en una inscripción hallada en la capital tribal de Lugdunum Convenarum (Saint-Bertrand-de-Comminges) dedicada al «genio de la colonia de los convenae» (AE 1957, 4).

Se puede deducir que tal colonización fue reciente si analizamos la mezcolanza étnica que aún muestran las inscripciones de la región: las hay de tipo familiar al mezclar parientes celtas con eusquéricos (p.e. Dannonia al ser hija de Harspi, o Rhexoni de 


\section{Nouvelle Revue d'Onomastique $n^{\circ} 54-2012$}

Hotarris), así como de tipo religioso al constatarse el culto observado por personas que portan nombres celtas a dioses de etimología eusquérica (p.e. Vernus Serani con Baicorixo deo), como por dedicantes con nombres eusquéricos que rinden culto a dioses indoeuropeos (p.e. Sabinus Barhosis con Abellioni deo, o Belex con Arpenino deo). Esta situación se explicaría mejor si se piensa en una mezcolanza reciente, ya que en otro caso se esperaría que tras siglos de convivencia hubiera prevalecido un único tipo onomástico a causa de una mayor progresión poblacional vía matrimonio, por mayor descendencia, o por aculturación.

Sobre la extensión que tuvo el territorio conveniano, podemos determinarlo muy aproximadamente según diversas fuentes antiguas. Es de suponer por Estrabón (Geog. IV, 1) que el territorio conveniano alcanzaba las cumbres pirenaicas:

... hacia los Pirineos, el país de los convenae, cuyo significado es «turba reunida», detentan la ciudad de Lugdunum así como las fuentes termales de los onesios, donde están las más bellas fuentes y las aguas más potables.

Estas fuentes eran las que se encontraban en la antigua Aquae Onesi, actual Bagnères-de-Luchon, ciudad igual de afamada por sus aguas curativas entre la burguesía francesa de los siglos XIX y XX. Tal vez el cercano río Oô conserve el antiguo topónimo, y las etimologías varían entre un celta *onno- «tilo» y un galo onno «río». Plinio (IV, 108) cita como una tribu aquitana a los monesios, pero ya se ha advertido que debe ser producto de un error de concatenación en la frase «infra quem onesi». Es interesante el topónimo Luchon porque en esa misma localidad se han encontrado inscripciones votivas dedicadas al dios tutelar de la ciudad: Ilixo(n) (ver CIL XIII, 345-348), y resulta que *ili es la palabra vascona de donde procede el vasco actual ( $h$ )iri «villa ; ciudad», palabra que está integrada mediante una variedad *ilun en los topónimos vascones de Pompaelo («Ciudad de Pompeyo», actual Pamplona), Andelo(n) (medieval Andión) y de *Iluberi («Ciudad Nueva», la actual Lumbier), ya mencionadas por Estrabón y Plinio. Así pues, si *ili es «ciudad», el sufijo -xo debe corresponderse al diminutivo vasco -txo, por lo que el significado debió ser «Ciudadela».

La antigua Aquae Convenarum (actual Capvern-les-Bains) estaría en territorio conveniano, lo que indicaría un cierto desbordamiento por el oeste de esta tribu.

Existió una Calagurris/Calagorris aquitana, la cual estaba incluida en el territorio conveniano (Calagorris Convenarum); esta ciudad estaba situada ente Tolosa y Lugdunum Convenarum según el Itinerario de Antonino, y se identifica con la actual Saint-Martory. Es la Calagurris a la que hace referencia San Jerónimo («Contra Vigilancio») cuando critica al herisarca por ser descendiente de aquellos hispanos deportados por Pompeyo a la comarca pirenaica a causa de su bandolerismo. Si bien la Calagurris del Ebro fue vascona, lo que nos ayudaría a identificar la lengua de muchos de los posibles fundadores/colonos de la nueva Calagorris, no se puede descartar que los vascones de Calagurris fueran hasta cierto punto alóctonos ya que la ceca de la antigua Calahorra tiene un sufijo y una declinación celtizante (kalakoRikos). También se da la casualidad (o no) que fue Calahorra una de las ciudades más fieles a la causa sertoriana, lo que haría más probable una mayor presencia de celtíberos en la Calagurris 


\section{El aquitano como lengua céltica (o vascones en Aquitania)}

norpirenaica en caso de haber sido renombrada. Además, este Vigilancio que tanto critica San Jerónimo era según escribió «un bárbaro, tanto en lenguaje como en conocimiento [religioso]», por lo cual se puede suponer que el vascón (o el celtíbero) aún se hablaba a finales del siglo IV en las zonas llanas de la comarca, ya que es cuando le dirige la carta a este antiguo compañero, pues aun sería demasiado temprano como para suponer un incipiente gascón (una crítica sobre su forma regional de hablar el latín tampoco es convincente al ser San Jerónimo una persona que ha recorrido medio imperio y está habituado a todo tipo de modalidades dialectales, además, Genadio en su obra De Viris Ilustribus, cap. XXXVI, escribe sobre él: «lingua politus, argutus et eloquens»). Sobre la etimología de este topónimo se ha escrito mucho, si bien todos los que lo han tratado descomponen el nombre en Cala-gorr $(i)$; pero es a la hora de encontrar el origen de cada elemento donde hay posiciones contrarias: unos prefieren comparar el primer elemento con el de las galaicas Caladunum y Cale (actual Oporto), así como con el de las galas Cala (actual Challes) y Calabrica Calodunum para ver en estos topónimos un origen en el IE *kal- «duro» o kal- «bello»; otros en cambio ven una raíz pre-celta *kala «villa» que sobreviviría en el francés chal-et «refugio de piedra», y que posiblemente se pueda vincular con la raíz indoeuropea *kel- «ocultar», ya que esta derivó hasta formas como el sánscrito sâla «casa», el griego $\kappa \alpha \lambda \iota \alpha$ «cabaña ; nido», o el latín cella «habitación»; otros por el contrario prefieren una explicación prendoeuropea con *kala «piedra ; fortaleza», explicación que se haría extensible para el segundo elemento al compararlo con el vasco gorri «rojo», sin poderse descartar tampoco una relación con la raíz IE * gher- «cercado» tal como destaca Curchin (2008).

Se sabe de las ruinas de una ciudad llamada Belsinum / Bersinum / Besino (TP 1,1 e IA 463,1) en el actual paraje de Boussen (comuna de Samaran, Gers), y que sería homónima de otra Belsinon que existió en el actual municipio de Mallén, mencionada en la Cosmografía del Ravenate (IV, 43) y en la Geografía de Ptolomeo (II, 6, 57), quien la situó en territorio celtíbero; sería mucha casualidad tener dos ciudades homónimas en territorios tan fuertemente vinculados, y de hecho, esta coincidencia podría ser tomada como un indicio sobre la extensión que tomó el asentamiento de hispanos en la Galia si consideramos este topónimo como un nombre trasplantado por sus fundadores, indicio que se refuerza cuando comprobamos lo cerca que estuvo Belsinon de Calagurris. Una explicación etimológica del topónimo se hace difícil: la posición de la Belsinon del Ebro en la actual frontera navarro-aragonesa no haría sino complicar su etimología, ya que si por una parte tenemos el vasco beltz «negro», por la otra tenemos según recoge Virgilio Gramático el celta belsa «campo»; además, Curchin (2008) opta por explicar el topónimo mediante la raíz indoeuropea *bhel- «resplandeciente ; blanco» o *bel- «fuerte ; grande».

Otros topónimos antiguos son provisionados por la epigrafía, y es mediante la lingüística que se puede intentar aclarar su origen étnico. Así, en la actual Boucou se encontró una dedicatoria al dios Bocco Harausoni, lo cual nos indica que se trata ciertamente de un topónimo antiguo. Esta deidad tiene la extraña característica de poder compartir rasgos celtas como vascos, así la raíz * mokku «cerdo» se encuentra además en otra deidad celta llamada Moccus (CIL V, 6650 y XIII, 05676), mientras que la otra parte del nombre remite al vasco herauts «verraco», el cual reaparece también en un teónimo

del País Vasco Francés (Heraus-corri-tsehe); un indicio así probaría que se dio 


\section{Nouvelle Revue d'Onomastique n $54-2012$}

efectivamente una mezcla de gentes de extracción vascona y celta, tal como parece desprenderse de la «traducción» o tautología y por la aplicación de un fonetismo eusquérico sobre la eme del elemento celta. Otros topónimos que existieron en época romana se pueden inferir también según la deidad tutelar de un lugar determinado como antes hemos visto con Ilixo y Luchon, así Horolati en Ore, Garre en el Mont Gar, Baesert en la iglesia de Nôtre Dame de Basert en Gourdan, y Arte / Artahe se halló en Saint-Péd'Ardet. A todos estos teónimos se les ha podido asignar fácilmente una etimología vascoide: Garre = harri «roca», Bae- = ibai «río», Arte = arte «encina». También en este caso se debería incluir el teónimo Lexi hallado en Les (Valle de Aran, Lleida - Année Epigraphique 1969/70, 276) y que no fue incluido en el trabajo de Gorrochategui (1984): «Lexi deo C(aius) Sabi(nus?) Hort(i) f(ilius)»; y también merece considerarse la identificación que hizo Joan Coromines con el teónimo Ele / Elhe y el lugar donde se hallaron las inscripciones votivas (Elp > Eup) mediante un hipotético *elhe-be «Bajo Elhe», como también ahora se puede proponer alternativamente que Elhe contienía una oclusiva aspirada tal como pasa en el elemento antroponímico conveniano Tauten / Hauten, por lo que tendrían que haber sido los romanceparlantes quienes la debieron conservar hasta hoy en día (se puede especular también en que este topónimo tuviera relación con una hipotética raíz vasca *elbhe con significado de «campo» y que estaría fosilizada en el vasco elkor / lekor / pekor, «terreno seco y duro», con un sufijo -kor, lo mismo que en malkor < *bale-kor, «lugar estéril», a los que se le podría añadir elur / elhur, «nieve, terreno nevado»). Otros teónimos que aparentan corresponderse con topónimos son Iluroni, Ilurberrixo e Ilumber-, puesto que contienen una raíz vasca ilur/ilun usada aún en numerosas ciudades (Lumbier de los antiguos ilu(n)beritani, Oloron que antiguamente era Iluro, Iruña, etc). Coromines identifica en el arroyo de Aret (comuna de Siraudan) el teónimo Aereda, en Bachòs (doc. Vaxosio, Baxosium) el teónimo aquitano Bascei pero con el sufijo prerromano -osse, Bourisp estaría formado con el teónimo Borix(s)us y el sufijo vasco -be (bajo), y Cuguron, Cuqueron y Cuguroo (Jumalàs) contendrían según él el teónimo Cucurus/Cugur. También han llegado hasta nosotros inscripciones con gentilicios que no pudieron ser analizadas por Gorrochategui por ser posteriores a su obra de 1984, como son las halladas en el alto valle del Aure, donde una hace referencia a unos conpagani llamados Harexuates (Anée Epigraphique $A E$ 2004, 911), mientras que la otra hace referencia a los conpagani Spariani (AE 1989, 509); y en el vecino valle de Oueil aparecen unos pagani Oollaies (AE 2001, 1376) que evidentemente toman el nombre al valle. Los tres topónimos pueden ser relacionados con el vasco, así Harexu- podría representar el actual haritz (roble), Spar(i)- podría ser variante de ezpal (astilla, gavilla), espal (astilla / fajo), aspel (fajo), azpira (artesa), ezpel (boj), o ezpara (tábano), mientras que *Oollai- podría estar relacionado con el vasco ola (cabaña).

Es indudable que la capital histórica de los convenae y del Comminges ha sido la antigua Lugdunum Convenarum (Lugdunum colonia en Ptolomeo), ciudad que pasó a conocerse durante la Edad Media simplemente como Convenica (que por evolución fonética gascona pasaría a *Cominja, dando así nombre a la comarca cuya capitalidad ostentaba). Su etimología prerromana, y por consiguiente su origen étnico, es claramente celta al igual que la vecina Lugdunum Consoranorum; esta está formada mediante el galo 


\section{El aquitano como lengua céltica (o vascones en Aquitania)}

lug, «brillante», y dunom, «fortaleza». Esta etimología parece indicar que ambos topónimos deben ser anteriores a la deportación de vascones e hispanoceltas, ya que estos últimos no usaban la palabra gala dunom para fortaleza, sino briga, y claro, de ser esta suposición cierta, se puede pensar que esta región debió ser «requisada» por Pompeyo a los poderosos volcos tectósages. Esta suposición tiene dos bases: por ser esta tribu conquistada en una fase posterior a la conquista de la Narbonense (y no se entendería que los romanos hubieran conquistado el Comminges antes sin haberse asegurado su enlace geográfico natural, y este no era otro que Tolosa de Lenguadoc, capital de los volcos tectósages), y porque la comarca del Comminges sería la que podría enlazar perfectamente los volcos de la Galia con los volcianos asentados entre el Pirineo y el Ebro (Livio en XXI, 19).

Una de las vías indirectas que existen para reconocer antiguos límites tribales, suele ser mediante la consideración de los límites episcopales, sobretodo cuando son reconocidamente antiguos; efectivamente, los obispos solían limitar sus áreas de influencia de acuerdo a los límites administrativos preexistentes impuestos por los romanos, creados en muchas ocasiones sobre una estructura tributaria pre-existente centrada en una capital tribal; entonces, esto mismo pudo acontecer con los límites de la Civitas Convenarum. Si nos guiamos por eso, veremos que los límites diocesanos respetaban las cuencas fluviales: toda la cuenca del alto Garona a partir de MartresTolosane excepto la cuenca de río Salat (perteneciente ya a los consoranos) era de la diócesis de Saint-Bertrand-en-Comminges, también la alta cuenca del río Save y todas las cuencas que median entre el Save y el Garona le pertenecían. Estos límites concuerdan casi a la perfección con los límites de la región histórica de Comminges, además de coincidir con los límites del antiguo condado de Comminges, el cual incluía originariamente el Valle de Aran (que decidió pasar a Cataluña en el siglo XIII).

Sobre el vecino territorio de los consoranos, su capital fue Lugdunum Consoranum (actual Saint-Lizier), y se piensa que fue creada o refundada por Pompeyo hacia el 72 a.C., imitando así su acción refundadora entre los convenae. Ahora bien, lo interesante es que el territorio de los consoranos debió desgajarse hacia la época de los Antoninos del territorio de Lugdunum para crear la nueva Civitas Consorannorum, lo que en definitiva parece indicar una antigua pertinencia de esta comarca a los convenae, cosa que pudo habilitar un proceso de colonización de vascones e hispanoceltas semejante al que parece que se dio en Lugdunum Convenarum y Calagorris.

\section{Segunda noticia sobre vascones en Aquitania}

Para el poeta burdigalés Ausonio (309-394), la Vasconia aún estaba situada en el Pirineo hispano (Carta XXV para Paulino):

\footnotetext{
¡Has cambiado de sentimientos querido Paulino! Eso es lo que hacen esos bosques de la Vasconia, esos pagos nevados del Pirineo... iy el olvido de nuestro cielo! ¡Son para ti mis justos reproches tierra íbera! ¡Que el cartaginés te devaste! ¡Que el pérfido Aníbal te queme! ¡Que el exiliado Sertorio te lleve la guerra!
} 


\section{Nouvelle Revue d'Onomastique $n^{\circ} 54-2012$}

Por el contrario, aún hizo mención a tribus reconocidamente aquitanas: «los campos de los tarbelos» (carta XXIII para Paulino), "el país de los bigerri, tu patria» (carta XI a Axio Paulo), «nació de la unión de un tarbelo y una eduana» (Parentalia - Emilia Eonia), «el océano de los tarbelos» (Parentalia - Cecilio Argicio Arborio), «de patria vasate» (Prefacio, II), "Cossio, municipio de los vasates» (Parentalia - Paulino). Así pues, no parece haber cambiado nada en la Aquitania romana en el aspecto indígena tras cuatro siglos de pax romana.

En cambio, los siglos V y VI fueron testimonios de dramáticas convulsiones politico-sociales que afectarán tanto la Vasconia como la Aquitania, de tal forma que será necesario establecer cohortes en Veleia (Nanclares de Oca, Álava) y en Lapurdo (zona de Bayona) para supuestamente controlar a los vascones («este Ebro que discurre entre los turbulentos vascones», escribe el poeta Rufo Festo Avieno en su Ora Maritima), no siendo mucho mejor la situación en el Alto Ebro tras las depredaciones de los bagaudae (campesinos rebeldes); tampoco las zonas costeras se podrán librar del pillaje, ya que sufrirán insistentes ataques piratas durante este periodo; igualmente no hubo paz en el norte tras el sucesivo paso de suevos, vándalos y alanos, paz que tampoco llegaría tras la ocupación del territorio aquitano por los visigodos (418), ya que esta conllevará algo más tarde la persecución anticatólica emprendida por el rey arriano Eurico (reinó entre el 466 y el 484), y no pasará mucho tiempo para que los visigodos fueran derrotados por los francos (año 507). Pero en este periodo de caos, guerras, pillajes y de tierras y gentes exhaustas destaca sobre todo una novedad acontecida en el año 587, novedad que quedó registrada en la Historia de los Francos (I, 9, 7) de San Gregorio de Tours:

Fueron los vascones quienes, irrumpiendo desde los montes, bajaron a la llanura, arrasaron viñedos y campos, incendiaron casas, y tomaron de ellas algunos prisioneros con sus ganados. El duque Austrovaldo procedió contra ellos muchas veces, pero no obtuvo sino una escasa venganza. ${ }^{2}$

Este pasaje nos plantea que los vascones eran independientes de los francos, y esto únicamente podía suceder al sur de la cadena montañosa. Además, esta razia no debió ser la única, ya que sólo aceptando una extensión en el tiempo de las actividades militares de los vascones explicaría que San Venancio Fortunato (530-600) jalease al conde burdigalés Galactorio para que "el vascón errante tema tu arma» (Libro X, 19), lo que indirectamente nos confirma que los vascones estaban provocando más problemas en territorio aquitano, y confirma que estos no eran nativos de la región, ya que no tendría sentido aplicar el adjetivo de «errante» a los nativos aquitanoromanos estando en su

\footnotetext{
2 Esto ya fue utilizado por Broca (1875) para defender de manera fundamentada una intrusión del vasco en Francia; si bien no dudó de la afinidad entre aquitano y vasco, el vasco de Iparralde sería producto de la invasión vascona del 587 y de una posterior colonización de la región, teoría que creyó confirmarse por las diferentes craniometrías existentes entre los vascos franceses (mayormente braquicéfalos) y los españoles (dolicocéfalos); por la unidad lingüística vasca, que no sería asumible en caso de ser la presencia allí demasiado antigua; y por la coincidencia de que la frontera vasca acabe en el mismo punto tanto en Francia como en España, algo que según Broca, sería indicativo de que los vascones rebasaron los valles de sur a norte, ya que tampoco se entendería que el navarro-aragonés y el gascón hubieran detenido su avance en el mismo punto.
} 


\section{El aquitano como lengua céltica (o vascones en Aquitania)}

propio país. En cualquier caso, parece que Galactorio debió fracasar en su intento de controlar la región, ya que gran parte de la Aquitania acabó efectivamente bajo dominio vascón (cosa que debieron aprovechar para asentarse en número importante a causa probablemente de la reciente ocupación visigoda del sur de la Vasconia original, si bien es cierto que otros historiadores niegan que esta presencia vascona en suelo aquitano represente movimiento poblacional alguno). Es el mismo Gregorio quien cuenta que en el año 602 los reyes francos Teodoberto II y Teodorico II marcharon hacia la Gascuña para restaurar su control sobre la región (lo que indirectamente significa que lo debieron perder durante algún tiempo), acabando por sojuzgar los vascones e imponiéndoles un $d u x$ franco como solución; una expulsión por parte de los francos de los recién llegados hubiera sido terrible, sangrienta y peligrosa. La memoria de aquella situación de caos y vacío de poder aún se recordaría en siglos posteriores:

Oyó San Amando que había una nación que la antigüedad llamó Vacceia, y que ahora llaman vulgarmente Wascona, presa de extremado error, de suerte que se entregaba a los augurios y a toda mentira, y también daba culto a los ídolos como si fueran Dios. Esta nación, hacia los bosques de los Pirineos, se hallaba diseminada por lugares ásperos e inaccesibles, y gloriándose de la habilidad que tenía para la lucha, ocupaba frecuentemente los términos de los Francos. Compadecido el varón del Señor, San Amando, por el error en que vivían empezó a trabajar para apartarles del servicio del diablo. (Vida de San Amando, de Baudemundo)

\section{Como también quedó registrado:}

En los primeros tiempos, cuando la Wasconia estuvo privada de condes, cuando los condes francos venidos de Francia rehusaban el condado por temor de la perfidia de los wascones y su costumbre de masacrar a sus condes... (Cartulario Negro de Sainte-Marie d'Auch)

La reconquista franca no supuso tampoco el control total de la región, ya que el poder de los reyes francos sobre la zona fue durante los siglos VII y VIII mayormente nominal e incluso nulo, viéndose forzados ocasionalmente a reconocer duques de clara filiación vascona (Eneco, Semen, Garcia, Menditarra...). En definitiva, nos encontramos ante un fenómeno que no fue exclusivo de esa época en Europa, ya que se pueden recordar los casos de migraciones como la de los refugiados britanos hacia la Bretaña francesa, o la de los piratas vikingos hacia la actual Normandía «Tierra de los Hombres del Norte», o la ocupación de la actual Lombardía por los bárbaros longobardos «barbas largas» tras haber sido expulsados de sus asentamientos por los ávaros...; de hecho, sería inexplicable que los actuales gascones hubieran tomado para sí su etnónimo (desde *wascones), si no fuera porque son descendientes de vascones. En fin, el cambio brusco entre aquitano y vascón/gascón se registra precisamente a partir del siglo VII en la Cosmografía del Ravenate, la cual nos confirma el cambio de nombre de gentes y región: "patria quae dicitur Guasconia, quae ab antiquis Aquitania dicebatur», además de precisar distinguir entre la nueva Vasconia de la original: «Item iuxta ipsam Guasconiam ponitur patria quae nominatur Spanoguasconia». Y ya por último, el hecho de que los vascones no llegaran a imponer su lengua entre los aquitanorromanos, indirectamente 


\section{Nouvelle Revue d'Onomastique $n^{\circ} 54-2012$}

contradice la teoría de una supuesta expansión occidental del vascón durante los siglos VVI, pues en el actual Euskadi la lengua vasca sí que se usa desde antiguo, por lo que la diferencia en la presencia lingüística sería un importante motivo para rebatir este caso.

\section{La onomástica aquitana bajo un nuevo enfoque}

\section{Topónimos aquitanos}

Los topónimos de origen eusquérico que no son registrados en época romana, no pueden ser usados con seguridad suficiente como para recrear la situación étnica y lingüística de la Aquitania prerromana; esto se debe a que la incursión y ocupación del territorio gascón por vascones a finales del siglo VI debió conllevar un aporte significativo de nuevos préstamos vascos al lenguaje y al registro de topónimos aquitanoromanos. Así pues, es razonable que muchos de los topónimos prerromanos noindoeuropeos que hallemos en Gascuña sean de origen histórico vascón y no tanto de origen protohistórico aquitano (incluso hay pueblos que harían referencia a asentamientos de inmigrantes vascones: Bascons y Bascous), lo que en definitiva nos impide tomar partida de estos topónimos a la hora de evaluar una antigua extensión de las lenguas preindoeuropeas ya que los conocimientos que posibilitarían una distinción entre topónimos vascos y topónimos prerromanos indígenas de tipo eusquérico no existen.

Al problema que supone no poder aceptar la gran mayoría de topónimos vascoides (excepto si cumplen con la premisa de estar atestiguados antes de la ocupación vascona), se le puede sumar el hecho de que el vascón haya ejercido de lengua de adstrato sobre el dialecto protogascón, lo que ha conllevado a que este haya adoptado préstamos de origen vasco que aún son utilizados en la actualidad; esto es un añadido a la dificultad de encontrar topónimos prerromanos de tipo eusquérico, ya que un topónimo como Biscarrosse podría ser de origen prerromano, o podría ser de origen vascón desde bizkar «lomo ; colina», o podría incluso proceder del gascón biscarrar «esquilar la lana de la parte lumbar», siendo este problema extensible a topónimos aparentemente prerromanos que hacen referencia a plantas o formas del terreno (p.e. Cuqueron podría ser el vasco kokor «cumbre»; Bun podría proceder del protovasco *buño > muino «colina», si bien se corresponde igualmente al occitano bonha, Aspin puede interpretarse mediante el vasco aizpe «gruta», procedente del vascón *aniz-bene, etc.). También deberían ser excluidas las terminaciones vascoides en -os de la Gascuña, ya que por sí mismas no sirven para rastrear la extensión del aquitano si tomásemos a este como una lengua eusquérica, puesto que este sufijo es claramente vascón y se halla distribuido en la patria navarra de los vascones y en el Pirineo Central (Jacetania, Sobrarbe, Ribagorza, Pallars y Andorra), regiones que además son identificadas por Plinio como vasconas; esto crea entonces un riesgo al intentar tomar esta clase de topónimos como de origen prerromano, ya que sería tal como pretender que la terminación latina -anum representase la extensión del latín en época prerromana allá donde aparece. Resulta que además, este tipo de topónimos gascones con sufijo -os paradójicamente no parecen haber sido utilizados en un contexto vascoide sino que por el contrario se ha usado más para nombrar fundus de personas con nombre galorrománico (Calvus $>$ Caubios, Valerius $>$ Baliros, Vitalis $>$ Vidalos, Vernus 


\section{El aquitano como lengua céltica (o vascones en Aquitania)}

$>$ Bernòs, Laurus $>$ Lauròs, Sapalus $>$ Sabalòs...) o directamente céltico (Triscos, Tarnos, Argelos, Gaillagos, Cambos, Tredós, Andernòs, Giscòs, Insòs, Sauròs, Targòs, Triscòs...). Una vez planteado el problema, se puede entonces concluir que los topónimos de tipo noindoeuropeo presentes en la Gascuña que se registran desde la Edad Media únicamente pueden servirnos actualmente para limitar la extensión máxima del vascón, pero no sirven para probar vínculos de afinidad entre el vasco y el «aquitano».

Toda esta problemática no es tan acusada para los topónimos basados en raíces o sufijos célticos, puesto que a menos que hayan pasado a ser patrimonio del occitano, no hay razón para creer en una expansión del celta tras la conquista romana (si bien hay casos en los que se puede incurrir a confusión etimológica céltica por una occitana: Broca acaso provenga del celta *brokko, «punta», pero en occitano una bròca es una asta; Morlanne podría ser del celta *morl- «colina», pero en occitano morlar es un verbo que significa tachonar zuecos, etc.).

Lo mismo que acontece con los topónimos, también se puede extender a la consideración de que los rasgos lingüísticos típicamente gascones sean un marcador y prueba de aquitanismo vascoide, ya que correríamos el riesgo de incluir características que en realidad fueron aportadas por el adstrato vascón, el cual debió influir en cierta manera sobre el habla de los aquitanorromanos. No tener en cuenta esa confusión nos llevaría lo mismo que a Gorrochategui (1984, p. 41) a unificar un hipotético substrato celta con el posterior adstrato vascón, haciendo así de dos uno:

La coincidencia entre los límites geográficos de la antigua Aquitania etnográfica [Novempopulania] y los límites lingüísticos del gascón permiten relacionar ambos fenómenos, de tal manera que el estado de cosas moderno sea considerado como consecuencia del estado de cosas más antiguo.

Este axioma por lo común es fundamentalmente válido, pero relacionar eso con el uso de una lengua eusquérica por parte de los aquitanos, eso ya no está nada claro; la atribución de coincidencias de rasgos fonéticos a un solo grupo lingüístico se tiene por falaz, y en este caso, es conocida la extensión de la aspiración de $f$ - latina el dialecto cántabro, con raíces étnicas celtas indudables y con una antigua y estrecha amistad tribal con los aquitanos (Julio César en $B G$ III, 26), a lo que se le debe añadir que el protocelta mismo eliminó la /p/ indoeuropea a través de un hipotético paso intermedio /f/; la reducción del grupo latino $-m b$ - también la comparte el castellano desde su nacimiento cantábrico; la tendencia al betacismo se extiende por toda la península, lo que nos hace preguntar si este es un rasgo únicamente atribuible al pre-indoeuropeo o a determinadas lenguas indoeuropeas con substrato no-indoeuropeo; la supresión de nasal intervocálica a causa de la nasalización de vocales tampoco es un rasgo que se circunscribe al área vascónica sino que tiene paralelos en el galaico-portugués, lengua romance que sustituyó a un grupo de lenguas indoeuropeas de tipo celta o cuasi celta (hay que tener en cuenta también que la nasalización vocálica se da en el idioma irlandés y en el francés, con un substrato galo). Igual planteamiento se puede hacer sobre el trato recibido por las laterales latinas: el gascón pasa -LL- a /r/, mientras que el vasco lo hace con -L-, pero también se comprueba que este trato se extiende en el galaico-portugués y en el romance ligur, donde 


\section{Nouvelle Revue d'Onomastique n $54-2012$}

se elimina -L-, mientras que en el asturiano se prefiere la palatalización de L- y -LL-. Además, ¿el rechazo a comenzar palabras con vibrante inicial se debe atribuir a los aquitanos o al efecto de adstrato del vascón medieval? ¿los préstamos lexicales en gascón de origen eusquérico proceden del fondo aquitano, o de la capa vascona? Existen más dificultades a considerar, así, ¿cómo entender que los rasgos más eusquéricos se concentren en las zonas montañosas? ¿por un efecto de mayor conservación en zonas aisladas junto a una mayor presencia celta en la planicie, o por una preferencia vascona por ocupar aquellas comarcas en las que podían continuar con su economía pastoril? ¿podemos realmente atribuir al aquitano rasgos fonéticos que se extienden sobre zonas ocupadas por galos (como la campiña de Burdeos)?, o dicho de otra manera, ¿qué razón debe haber para que los rasgos fonéticos típicos del gascón desborden el territorio étnico de los aquitanos (Novempopulania)? ¿podemos asegurar que el vascón no sufrió influencia alguna de sus vecinos celtas y que por lo tanto no adquirió rasgos fonéticos de estos y que ahora no se confundiría préstamo fonético por pertenencia? ¿Cómo se justificaría que el navarro-aragonés apenas presente esos supuestos atributos eusquéricos cuando tenemos por cierto que el Pirineo occidental y central fue ocupado por vascones desde antiguo? ¿Y si los supuestos rasgos fonéticos pre-indoeuropeos en el gascón valen para hacer al aquitano una lengua pre-indoeuropea, qué consideración deberían tener aquellos rasgos que también posee y que se atribuyen al celta?. Como se puede ver, la ecuación de que el vasco, el aquitano y el gascón comparten rasgos fonéticos a causa de proceder de un antiguo fondo común está lejos de ser segura. Si bien más abajo se intentará responder a estas preguntas, cuya respuesta es más bien contraria a la existencia de un substrato vascoide, lo único que sí que se puede asegurar por el momento es que el vascón tuvo contacto con el celta y recibió préstamos de léxico, y que el vascón influyó sobremanera en la fonética del antiguo castellano a causa del aporte poblacional de vascones en la colonización de tierras reconquistadas a los musulmanes (principalmente en La Rioja, Burgos, Soria), efecto que podría hacerse extensible igualmente al gascón cuando los vascones ocuparon con más o menos intensidad las antigua Novempopulania.

Una vez reconocidas todas estas problemáticas como producto de dos estratos diferentes, es entonces cuando podemos recurrir únicamente a los topónimos registrados con anterioridad a las incursiones vasconas del siglo VI, así como a aquellos topónimos modernos de origen celta que no se puedan confundir con algún gasconismo, de tal manera que podemos observar una presencia céltica mucho mayor de lo que se ha admitido hasta ahora, así, los topónimos de tipo eusquérico casi parecen reducirse a colonias de origen íbero (puestos comerciales para explotar los recursos mineros o fundaciones al modo helénico), o a poblaciones del actual País Vasco Francés y región conveniana.

\section{Topónimos aquitanos: Aquitania - Novempopulania}

A continuación, se hace un listado con los etnónimos y topónimos prerromanos de la región comprendida entre el Pirineo y el Garona y que conocemos gracias a autores clásicos como Ausonio, Ptolomeo, Plinio, Julio César, o Estrabón; además, disponemos también de la ayuda que nos brindan documentos utilitarios más tardíos: la Tabla de 


\section{El aquitano como lengua céltica (o vascones en Aquitania)}

Peutinger - TP, el Itinerario Antonino - IA, la Notitia Dignitatum - ND, y el Itinerario Burdigalense - IB (para la situación geográfica aproximada de cada tribu, véase la figura núm. 1; en el listado se ha atribuido cada topónimo a una tribu determinada según la distancia que hay hasta la capital tribal, sin que eso represente que se hallara verdaderamente en el territorio de dicha tribu (para consultar detalles y bibliografía sobre cada topónimo, ver DAUZAT \& ROSTAIGN, 1963; IRIGOYEN, 1987; GORROCHATEGUI, 1995，2005; MORVAN，2004; DELAMARRE， 2003); los topónimos que no cuentan con una explicación etimológica son simplemente anotados, si bien para evitar esta deficiencia lo máximo posible, se ha usado ocasionalmente en este artículo el diccionario etimológico celta de Matasovic para intentar suplir posibles etimologías, por lo que deben ser tomadas con toda la precaución debida, en todo caso, se han marcado las raíces atribuidas mediante subrayado; no se recogen todas las variantes onomásticas menores conocidas):

- Bituriges viviscos: bituriges significa «reyes del mundo» en celta, y procedían de una escisión de los Bituriges de la zona de Bourges; vivisco no tiene en cambio una etimología celta segura, pero parece relacionado con una población alpina llamada Vivisco (TP 2,3). La capital era Burdigala, actual Bordeaux, topónimo con una dudosa etimología eusquérica propuesta basada en el vasco burdin «hierro», si bien antes sería preferible entonces compararlo con el vasco borda «cabaña», el aragonés buerda, el gascón bòrda y el catalán borda, cuyo origen como préstamo godo ha sido cuestionado por su peculiar extensión «filo-pirenaica»; en cualquier caso debe tener algún tipo de conexión Burdua (lusitana), Burdoga (bética), y tal vez también con Burtina (ilérgete y/o suessetana) y Burticum (tracia); Dauzat y Rostaign prefieren compararlo con el gascón burd «marisma, ciénaga», siendo este una evolución local del preromano *bard «barro» según se reconstruye mediante el occitano bard, el aragonés bardo, el vasco barda, el mozárabe barra, el galo bart «argila» y el castellano barro; en cuanto al segundo elemento, se puede comparar al que está presente en Calagurris, Caladunum, Caleva, Cale, Cala, y Calodunum y que antes ya hemos visto que procede seguramente de la raíz indoeuropea *kal«duro» o *kel- «ocultar» y que habría sobrevivido en el francés chalet y en el occitano cala. En cualquier caso, es muy probable que la actual Bordighera ligur explique con mayores garantías el significado de Burdigala. Es indudable que la lengua de los bituriges fuese la gala ya que el herborista burdigalés Marcelo, en su obra De Medicamentis Liber, nos da varias traducciones al galo de plantas curativas; y también es otro burdigalés, el retórico Ausonio, quien alabó en su obra Ordo Urbium Nobilium una fuente de Burdeos «llamada Divona < divina > por los celtas», mientras que la misma fuente era conocida como Pario por los latinos (es la actual Font de Devèze); Estrabón (Geog. IV, 1) certifica contundentemente el galismo de los bituriges: «El Garona, después de acrecentar sus aguas con las aguas de tres ríos, descarga sus aguas en la región que hay entre los bituriges viviscos y los santones, siendo ambas tribus galas». En el aspecto arqueológico, en la región biturige se manifiesta hacia el 


\section{Nouvelle Revue d'Onomastique $n^{\circ} 54-2012$}

siglo IV a.C. la aparición de cerámicas y tumbas de tipo lateniense (GARDES, 2001), siendo el resto de regiones aquitanas poco permeables a esta nueva influencia septentrional.

- Medulos: en la península del Médoc, tal vez basado en el celta *medu«hidromiel», o mejor de alguna variante regional de *medyo- «medio, central». Deben estar relacionados los medulos de los Alpes y el monte Medullus del Bierzo. En la península estuvo Noviomagus (comuna de Saint-Germaind'Esteuil), que significa «lugar nuevo» en galo. Ptolomeo indica que el nombre del cabo donde acaba esta península era Curianum, que podría tener el mismo elemento que la tribu hiberna de los coriondos. Coffin $(1986,56-57)$ señala que las excavaciones efectuadas en esta región y en otros puntos del departamento de la Gironde muestran la aparición de elementos culturales galos (o de la Cultura de La Téne) hacia el siglo V a.C.

- Boios, boiates, vocasates o vocates: serían una rama de la tribu celta de los boios del centro de Europa (Bohemia les debe su nombre) y del Bassin francés; estos tenían la capital en la antigua Boios / Civitas Boiatum (actual Biganos) y transmitieron su tribónimo a la comarca gascona del País de Buch. Este tribónimo estaría lejanamente relacionado con el galés $b w g$ «terrible». Se trataría por lo tanto de una tribu de habla céltica, pero no gala, tal como acontecía con la cercana tribu centroeuropea de los Volcos Tectosages «Volcos buscadores de techo», con capital en Tolosa. La región que ocuparon se distingue del resto de las llanura gascona por haber proporcionado dos necrópolis en las que la urna cineraria no era cubierta por un túmulo: Truc de Bourdiou en Mios y Martinet en Salles.

- Sennios, seniones, o sennates: de localización incierta, aunque si debieran su etnónimo a la ciudad de Senone o Serione o Sirio (ahora Pont du Ciron, Barsac), serían vecinos de los vasates y de bituriges. Su etimología celta es clara (galo *seno-, «viejo, antiguo»). Esta tribu podría estar igualmente relacionada con unos senones situados en una región cercana a París y el río Sena (Sennais); se da el caso que buena parte de esta tribu emprendió en el siglo IV una emigración que los llevó hasta la Galia Cisalpina, donde perduró una rama de esta tribu; no sería demasiado especulativo entonces pensar que otra rama de esta misma tribu pudo dirigirse a la más cercana Aquitania. Es harto curioso que tres tribus del Bassin francés (boios, bituriges y senones) tengan sus homónimas en una misma zona aquitana.

- Vasates o vasseos: su capital era la actual Bazas (antigua Cossio), cuyo nombre está relacionado: Civitas Vasatica. La etimología puede ser tanto vascoide (baso $=$ «bosque»), como céltica $(*$ was- «bajo», de donde pasó como préstamo un derivado celta al castellano "vasallo»; también puede proceder de *wostu«morada»), si bien es preferible la opción céltica por la semiconsonante inicial, inadmisible en el protovasco. Una fracción de esta tribu debió quedar integrada en la de los boios, ya que se constata la existencia de unos basaboiates. La villa de Langon es referida por Sidonio Apolinar (Epist. VIII, 12, 3) como portum Alingonis, estaría relacionada con la gala Alingavia, cuya etimología celta sería 


\section{El aquitano como lengua céltica (o vascones en Aquitania)}

*ad-ling- («Gran Salto»). Otra villa en la región: Stomata.

- Belindos: centrados en torno a la actual Belin-Béliet; el tribónimo puede contener la raíz céltica *bel- «golpear», o también puede contener para Curchin (2008) las raíces indoeuropeas *bel- «fuerte ; grande», o *bhel«resplandeciente ; blanco», de donde partió el celta belenios «beleño» y el teónimo celta Belenos, aunque para Pere Bosch-Gimpera, su celtismo quedaba asegurado cuando se relaciona su tribónimo con el de los pelendones de Soria; tal vez otra comparación posible sería con los blendios de la antigua Cantabria. El celtismo de Losa (actual Louse, com. Sanguinet) se puede confirmar con el celta *loxso- «oblícuo, bulboso» y que está presente también en el antiguo río caledonio Loxa, mientras que el de Salomacum / Salomagus (actual Salles) es evidente al poderse traducir mediante el celta como «lugar de la sal» o «lugar pantanoso»; las etimologías para el río Sigmatus o Sigmanus (Leyre), o para la antigua Tellonum (Saugnacq-et-Muret), no resultan tan evidentes, si bien para el hidrónimo, el grupo consonántico -gm- es inaceptable para el vasco antiguo, mientras que la variante Signatios que recoge Marciano de Heráclea (Periplus maris exteri II, 21) podría contener un elemento que se correspondería con el galo gnato- «nacido, surgido», por lo que $\mathrm{Si}$ - pasaría a corresponderse a *si «ella; ella misma»; Tellonum sería en todo caso homónima de la igualmente antigua Telonnum (actual Toulon-sur-Arroux, en la región de Borgoña).

- Cocosates: en el sur de las Landas, con capital en Caequosa o Cocosa (cerca de Sindères); el vocalismo del topónimo no puede ser vascoide, por el contrario, podría relacionarse con otros topónimos celtas como Cocconis, Coccium o Cuccium, todos ellos derivados supuestamente de la raíz celta *kokko- «rojo», según se puede reconstruir a partir del galés medieval coch «rojo», del latín coccineus «escarlata», y del griego коккоб. Otras ciudades: Mosconium (en la comuna de Lit-et-Mixe), topónimo que compartiría la misma raíz que tres hidrónimos galos: el Moselle (antiguo Mosa flumen, cuya raíz se relaciona con el irlandés mosar "salado»), el Mouzoin, y el Mozanne; Segosa (actual SaintPaul-en-Born), cuya raíz es el celta *sego- «fuerza» y contiene un sufijo -osa que se ha identificado también en Dertosa (ilercavona), Tolosa (volca tectosaga), Caequosa (cocosate), Succosa (suessetana-ilérgete), Metercosa (carpetana) y Egosa (castellana).

- Oscidates: situados entorno a la antigua Oscineum / Oscincio (posiblemente en la actual Escinjot, com. Houeilles); tal vez deban su nombre a la correspondecia del galo *oska «muesca» (ouche en francés), si bien hay que tener en cuenta que el vasco ha tomado prestada esta misma palabra a través del gascón $(o s c a>o z k a)$. De la misma región de Houeilles habrían partido los oscidates montani para ocupar algún valle pirenaico (al conservar el nombre de su capital en su tribónimo, este indica que la formación de esta tribu fue posterior a la situada en el llano); a su vez, los oscidates del llano recibieron el sobrenombre de campestres. Una ciudad en el entorno oscidate fue Vesubio o Ussubium (Le Mas d'Agennais, CIL 13, 919), que puede contener el celta *wesu- «bueno» o *ux- «altura» dependiendo de que variante es la más 


\section{Nouvelle Revue d'Onomastique $n^{\circ} 54-2012$}

próxima a la original. El antiguo nombre de Caumont-sur-Garonne parece ser que fue Vernemetis (en IA y en Venancio Fortunato en Carmina, I, IX, 9), homónima de otra Vernemetis britona y cuyo significado sería «gran lugar sagrado» ya que en galo ver- es «grande» y nemeto- es «santuario, bosque sagrado», aspecto que recoge el mismo obispo: «quod quasi fanum ingens gallica lingua refert».

- Sotiates o sociates: capital en la actual Sos-en-Albret. Los topónimos antiguos que se vinculan con la capital sotiate como Scittio o Scotio parecen contener errores en su transmisión ya que la raíz del tribónimo, si efectivamente deriva de la capital de la tribu (*Sotio), habría evolucionado precisamente hasta la actual Sos, villa que fue documentada como Sitio y Sotiatum en la Edad Media.

- Lectorates: con capital en Lactora > Lectoure, cuya etimología podría adjudicarse a una metátesis vocálica desde un cognado del galo lucterio- y del galés llwyth «fardo ; tribu». Plinio no menciona a los lactorates, pero en cambio sitúa a unos cambolectros en Aquitania (IV, 108), por lo que puede suponerse que este pudo confundir los lactorates con los cambolectros de la vecina Gallia Narbonensis (III, 36). Cerca de Lactora estaba la antigua Sarralis o Sartalia (ahora Sarrant), cuya raíz podría compartir con el río Sarthe.

- Elusates: con capital en Elusa (actual Eauze); esta ciudad también se identificó con la antigua Tasta, pero esto se muestra erróneo, ya que Tolomeo confundió la situación de la capital de los daties, pues esta estaba en la región del valle del Daze y no en Gascuña. Existió una ciudad homónima llamada Elusio / Elisidunum (medieval Alsona, actual Montferrand) en el no demasiado lejano territorio de la tribu ligur de los elisices; para esta Elusio se sospecha una base céltica *aliso «aliso».

- Auscios: con capital en Augusta Ausciorum o Civitas Auscius (ahora Auch); el tribónimo podría estar vinculado con el antropónimo celtoligur Auscrocos, y ambos contendrían el protocelta * $\underline{a w s}$ «oreja», ¿tal vez «los orejudos»?; se ha pretendido ver en este tribónimo una base similar a la que contiene euskera «lengua vasca», pero la formación de esta palabra parece que hay que remitirla al protovasco *enus- "hablar», con un sufijo -kera "forma». Los topónimos registrados en la zona de influencia ausca remiten al celta: Casinomagus o «lugar de encinas» en celta (cerca de la actual Gimont), Condate > Condom desde *kond- «confluencia», y Vanesia, que según Coromines tendría una raíz celta *wenia «linaje, parentaje» sufijada con -isi- como en Bergusia, es una villa que se ha situado en la rivera del Baïse (Moncaubet, com. de Saint-JeanPoutges). La única excepción de celtismo aparente sería el antiguo nombre de la capital de la tribu ausca: Eliberre o Elimberrum Ausciorum, topónimo con homónimos en el Rosellón, Navarra y Granada, por lo que podría pensarse que se trata de un topónimo fundacional de origen íbero o vascoide (*Ili-berri, «Ciudad Nueva»); en todo caso A. Castagn (1885) ya advirtió que la forma original fue Climberrum (con una variante Cliberre), tal como se lee en Pomponio Mela y en el Itinerario Antonino, siendo Elimberrum una ultracorrección del siglo XVIII que ha sido transmitida hasta la actualidad. 


\section{El aquitano como lengua céltica (o vascones en Aquitania)}

Otro topónimo que presenta dificultades es el de Hungunverrum o Hungunnerum, cuya etimología es igualmente insegura, si bien -verrum se ha querido comparar con el vasco berri «nuevo», aunque esta misma etimología nos llevaría a dudar sobre el indigenismo del topónimo, ya que si Hungun- fue «nuevo», eso quiere decir que basa su nombre en una *Hungun más antigua, que en caso de haber sufrido una asimilación vocálica, podría situarse en la medieval Angonia (la actual población fronteriza con el Comminges de Martres-Tolosane, cuya etimología se base posiblemente en el celta *ango-, «estrecho»): otra etimología sería una derivación del hipotético primer elemento desde el celta *bu-n-g-o «romper», u otra posibilidad es que comparta el mismo elemento que la antigua Vungovicus (actual Voncq), en todo caso, el segundo elemento se correspondería entonces con la raíz celta *werro- «altura», o alternativamente con *berso- «corral» según se deriva del bretón berr, del galés byr, o del irlandés ber. De todas formas, cabría añadir otro indicio para aducir eusquerismo en este topónimo por la presencia de una aspirada, pero antes se debería asegurar que su presencia no se deba a un error de copistas, o a que el celta de la región no hubiera desarrollado la aspiración tal como el gaélico y el irlandés, lenguas estrechamente emparentadas que ya muestran aspiración por lo menos desde el siglo $\mathrm{V}$ d.C., coincidiendo por lo tanto con el momento en que se separaron del tronco común goidélico. También tiene su interés cómo se ha desarrollado la aspiración desde /g/ en dialectos gallegos (geada): /hrande/, /haita/, etc.

- Tarbelos: con capital en Aquae Tarbellicae, actual Dax. Dado que muchas tribus tomaron su nombre según su capital, es posible que los biguerrones debieron ocupar su capital primigenia, Taroduno / Tarva / Turba (actual Tarbes). El etnónimo puede remitirse al celta *tarwo- «toro», si bien Gorrochategui prefiere una explicación eusquérica descomponiéndolo en Tarpara relacionarlo con un topónimo pre-IE (Tarros) y -bel para compararlo con el sufijo vasco -bel «negro, oscuro». Fue controlada por los tarbelos según reza una inscripción funeraria saguntina (CIL II, 14-00625) la antigua Narbona (actual Arbonne, País Vasco Francés), siendo por lo tanto homónima de la Narbona ligur de los elisices y muy parecida al etnónimo de los narbasos galaicos. La inclusión del actual territorio vascoparlante al norte de los Pirineos como asignado a tarbelos, recibe confirmación indirecta desde Tolomeo, al repartir este el Pirineo aquitano entre tarbelos y convenae, lo que conlleva a incluir el País Vasco Francés como tarbelo. El territorio de los tarbelos incluyó también territorios de otras tribus menores como los ilurenses de Iluro (Oloron) y los benearnos de Beneharnum (Lescar).

- Aturios o tarusates: establecidos entorno a su capital Atura o Attires (actual Aire-sur-l'Adour), ciudad bañada por el río Adour al que le debe el nombre (para los vascoparlantes es el Aturri); la etimología sería celta: el irlandés $d u r$ «ribera», el galés $d w r$ «agua» y el bretón dour «ídem» podrían tener un cognado galo que estaría presente en la base de otros ríos como el Dordogne (antiguo Duranius), el Durance, el Dronne, el Drôme, el Dora del Valle de 


\section{Nouvelle Revue d'Onomastique $n^{\circ} 54-2012$}

Aosta, y en el del mismo Duero/Douro... así como el Durio de la antigua Hibernia. Una etimología alternativa vasca basada en iturri «fuente», es menos probable a razón del vocalismo y de la semántica. Se puede suponer que la comarca del Tursan debe el nombre a los tarusates lo mismo que en la población de Vielle-Tursan debe estar el origen del tribónimo y de su antigua capital; quedaría por dilucidar entonces si estamos ante dos tribus vecinas que fueron confundidas, o si un cambio de capital mudó también cómo era conocida. San Gregorio de Tours (De gloria confess., 59) hace mención de una iglesia de Atroa en Vici Juliensis, que se debe corresponder con la actual pueblo de Arue; el grupo de muta cum liquida es inaceptable en eusquérico, por el contrario, el topónimo muestra una buena afinidad con el protocelta *adtreba $>$ *attreba «asentamiento», de donde procede por ejemplo el etnónimo galo de los atrebates, así como forma parte del topónimo celtíbero de Contrebia.

- Benarnos o venarnos (son los mismos que los venamos de Plinio, pero esta variante es seguramente producto de una confusión entre $\mathrm{rn} / \mathrm{m}$ ): ocupaban el actual Bearn, topónimo que registra la evolución gascona de eliminar nasales intervocálicas y de ser betacista. Su capital primitiva pudo ser Beneharnum, que deja de ser mencionada tras las razias vasconas para pasar a ser substituida por Lascurris (actual Lescar), topónimo que parece contener el vasco lats «arroyo» y gorri «rojo». Beneharnum, se podría vincular con el vasco * bene > behe «bajo», pero si la variante del tribónimo venarnos es la más fiel a la pronunciación, esta incluye una posible semiconsonante poco afín a la fonética del vasco antiguo, tampoco la posición de adjetivos en posición inicial no es aceptable en vasco. Una etimología celta para el hipotético elemento Veneestaría en la raíz *wena-, *weni-, de donde procedería el antiguo irlandés fine «gente», antiguo bretón guen «raza», y que contendría el tribónimo caledonio de los veniconi.

- Ptianos, pthianos, pthucanos, pacianos, procianos, p(re)cianos, o lacianos: variantes de un tribónimo que es mencionado únicamente por Julio César, por lo que se ha querido pensar que sustituirían a los venarnos. En vasco antiguo no son admisibles ni dos oclusivas juntas ni grupos de muta cum liquida, por lo que la etimología debe ser indoeuropea, si bien es difícil determinarla a causa de las variantes existentes.

- Ilurenses: el tribónimo procede claramente de la antigua Iluro o Eluro (actual Oloron-Sainte-Marie), topónimo que contiene la palabra vascona o íbera *ili «ciudad», siendo además homónima de la Iluro catalana (medieval Alarona) y de la andaluza (actual Alora). Los ilurenses debieron ocupar consecuentemente el Valle de Aspe, conocido antiguamente como Aspaluca, Aspalluga o Aspalunga (Accous); si bien este topónimo se ha querido interpretar mediante el vasco aizpe «peña» $\mathrm{y}$ con un segundo elemento por determinar, tal interpretación es dudosa cuando la reconstrucción del vasquismo es *aniz-bene (lit. «roca-bajo»), y no hay constancia de nasales en el primer elemento del topónimo romano, por lo que entonces se debería pensar en otra alternativa 


\section{El aquitano como lengua céltica (o vascones en Aquitania)}

como un derivado que fuera cognado del vasco espal «gavilla ; bala» o aspel «fajo de helecho, heno» o ezpel «boj». Es de destacar que los dialectos occitanos de los valles ilurenses mantienen características propias del vasco, como conservar las oclusivas intervocálicas latinas, o hacerlas sordas si son precedidas por $/ 1, \mathrm{~m}, \mathrm{n} /$ (de igual forma, en las zonas llanas del antiguo territorio ilurense hay características que hacen sospechar que allí también se dieron esos rasgos lingüísticos tal como ya advirtió Saroïhandy). Esta región se distingue del resto de Aquitania (junto al País Vasco Francés) por no tener poblaciones con el sufijo celta -acum. Además de las características noindoeuropeas que presenta esta región en toponimia o en fonetismo, esta se distingue junto al vecino País Vasco Francés por tener restos de estructuras funerarias creadas durante la Edad del Hierro formadas por un círculo de piedra o «cromlech», estructuras que se atribuyen por lo común a poblaciones eusquéricas.

- Campones: se cree que estarían en la zona de Cambo-les-Bains (actualmente en territorio vascoparlante, lo que justificaría la sonorización de la segunda oclusiva sorda por estar precedida por $/ \mathrm{m} /$ ); la etimología resulta clara con el celta: *kambo- «curvo > meandro», raíz compartida con la antigua ciudad britona de Cambodunum. Esta localidad estaría en la región vascoparlante de Lapurdo (actual Labourd / Lapurdi) según la Notitia Dignitatum, y se puede corresponder a un vasco lapur «ladrón» con posible evolución semántica hasta «pirata» y sufijo -di que indica colectividad.

- Bercorates, de localización desconocida; tal vez el etnónimo contenga una raíz vinculable al galo vergo- «eficaz», y que parece estar presente en el $N L$ britón de Vercovicum; tampoco se puede descartar que contenga una raíz «celtoligur» derivada del proto-indoeuropeo * bhergh- «montaña, altura», de donde procede en su caso el celta *brig- «altura, otero ; fortificación», el germánico *burgs «fortzaleza», o el griego $\pi v \rho \gamma o \sigma$ «torre», por lo que entonces, la hipotética capital de los bercorates (*Bercora) pertenecería al mismo grupo que Bergidum (suessetana-ilérgete), Bergusia (suessetana-ilérgete), Bergidum Flavium (en el Bierzo), Bergintrum (en la Saboya), Bergusium (en el Delfinado), Bergoiata (en Provenza), y Bergomum (actual Bérgamo), así como otras villas que han conservado esta raíz pero de las que no hay documentación antigua: Bergamasco, Berga, Bergara, Berganza, etc. La localidad aquitana que más se avendría a haber sido esa hipotética *Bercora sería la actual Bergouey (Burgue en el bajonavarro local): porque Orpustan no le halla una etimología vasca satisfactoria, y por estar en un lugar con un vacío tribal entre lapurtanos, sibulates y tarbelos; resulta además que Plinio los menciona junto a otras tribus del País Vasco francés. En su territorio se incluiría el topónimo de Carasa, de interpretación vascoide (*Kharre-tsa > harritza 'roquedal») y que aún subsistiría en el topónimo local de Garazi (Cize en gascón, registrado como Cisera en 1150); otros han abogado por identificarla con Garris.

- Sibyllates, sibulates, o sibuzates: tribu que toma su nombre del valle vascoparlante del Zuberoa (Soule en francés), ya documentado en el siglo VII 


\section{Nouvelle Revue d'Onomastique $n^{\circ} 54-2012$}

como Subola. Orpustan (2004) propone relacionar la raíz del etnónimo con el vasco zubel «encina». Como se ha comentado anteriormente, en el País Vasco Francés se encuentran en las zonas montañosas estructuras funerarias de la Edad del Hierro consistentes en círculos de piedras o cromlechs; también en la región se documentan en las zonas bajas túmulos funerarios de tierra, y que a diferencia de los gascones, suelen delimitarse con un cromlech. Esto es muy interesante, ya que la diferencia geográfica de tipologías funerarias entre montaña-valle se puede explicar por un diferente ámbito socio-económico entre gentes dedicadas al pastoreo en la cadena montañosa y gentes dedicadas a la agricultura que permiten las riberas; luego, la aparente mezcla de tipos funerarios que se observa en los valles se puede interpretar como una adaptación entre los constructores vascoides de cromlechs de determinadas influencias septentrionales, o bien por ser producto de la adaptación por parte de gentes aquitanoparlantes de unas costumbres (¿y lengua?) que debieron traspasar la barrera pirenaica.

- Vellates: se les atribuye el actual topónimo de Puerto de Velate, por lo que estarían asentados en el Alto Bidasoa, en la región vascoparlante de Baztan. El tribónimo se podría interpretar mediante el celta *welo- «bueno, deseable», aunque también sería aceptable compararlo con el galo vellos «mejor» y su cognado bretón gwall y galés gwell, siendo de todas formas la raíz que contiene muy similar a la de la Vellica cántabra, o a la de la tribu hiberna de los vellaborios; una explicación mediante el vasco se hace difícil por el problema de la semiconsonante y porque la aproximación más cercana sería con el protovasco * bil «redondo» o con el sufijo - $\underline{b e l}$ «negro, oscuro».

- Pinpedunos o bipedimuos: tribu pirenaica según Plinio que se puede interpretar mediante la ayuda del galo pimpe-dunos «cinco fortalezas» (bipedimuos parece ser el resultado de una deficiente transmisión oral del tribónimo); casualmente existe la región de las Cinco Villas en el Bidasoa Medio (Lesaka, Arantza, Iantzi, Etxalar y Bera). Es muy interesante este etnónimo porque en caso de haberse originado desde el idioma aquitano y no desde una presencia puntual gala, demostraría que este perteneció al grupo de lenguas P-Celtas junto al mismo galo, el britón, el lepóntico, o el galés (por producir /p/ desde la labiovelar $/ * \mathrm{kw} /$, aquí sería entonces desde el protocelta *kwenkwe), alejándose al menos por lo que sería a esta característica evolutiva del grupo Q-Celta, el cual incluye lenguas como el celtíbero o el irlandés. Sería interesante saber si el celta de cántabros, carpetanos, vacceos o astures perteneció a un grupo u otro, así como también sería interesante determinar con suficiente conocimiento de causa si antropónimos como Pintius, Epeicus, o Mapalia, teónimos como Epona, o localidades como Pintia, se deben tal como creen algunos historiadores por una moda gala y por una presencia de mercenarios galos, o a que hubo también una antigua penetración en Hispania de P-celtas tal como propone Francisco Villar.

- Sediboniates: de localización indeterminada; tal vez derivan su etnónimo desde una ciudad principal *Sedibona, que tendría la misma terminación céltica que 


\section{El aquitano como lengua céltica (o vascones en Aquitania)}

Vindobona (Viena) «Fundación Blanca» o Augustobona, pues están formadas mediante el protocelta *bonu «fundación, base»; entonces Sedi- debería corresponder al celta * sedo- «calma; paz».

- Onobrisates u olobrisates: no se ha localizado el territorio de esta tribu, aunque la similitud que tiene con los onesios ha hecho pensar que estos serían una fracción de este pueblo. El etnónimo parece contener un primer elemento que sería el galo onno «río» o el celta *onno- «tilo», junto a un segundo elemento galo *bris «corte»; este tribónimo no sigue una norma fonética del vasco antiguo: aversión a muta cum liquida, por lo que sería descartable una interpretación vascoide.

- Tribus de situación ignota son los tornates (la raíz sería cognado del galo *turno- «altura»), así como los gates (o gaites, o garites). Sería erróneo incluir a los velaunos que menciona Ptolomeo en la Aquitania primitiva ya que se trata de uno de los numerosos errores geográficos que comete el geógrafo, puesto que la posición exacta de esta tribu está en la Alvernia, en el país de Velay.

- Los succasos también son de localización indeterminada; el etnónimo compartiría la misma raíz celta que la Succosia gala como la de la antigua ciudad oscense de Succosa, ya fuera esta raíz proto-celta *su «bueno» seguido de *kassi «rizo», o con *sukko- «cerdo».

- Lassunos o sassuminos: entorno a la antigua aldea de Lassun (Montaut). Una ciudadela: la antigua Novioduno («fortaleza-nueva» en celta), que fue latinizada como Oppidum Novum (actual Lourdes o Nay).

- Bigerrones, beguerros o bigorrenos: de donde la actual comarca de la Bigorra (que para Irigoyen procedería del vasco bai-gorri «río-rojo» y no tendría relación con el tribónimo). El etnónimo podría derivar del vasco biur «lazo, atadura» o de bihurri «torcido / malvado, retorcido» si se adoptó una /g/ para evitar el hiato. También sería posible pensar en algún tipo de relación etimológica con la antigua ciudad íbera de Bigerra, en territorio bastetano (sudeste de España). Y cabe también la posibilidad de comparar el tribónimo bigorrio / bigerrón con el celta * bego- «romper». Los topónimos antiguos que se conocen para esta tribu son exclusivamente celtas: Taroduno / Tarva (Tarbes) procede del celta *tarwos «toro», conteniendo Taroduno el típicamente galo duno "fortaleza», y se podría vincular este topónimo con la Tarbonia ligur que aparece en la Tabula Alimentaria de Veleia (6, 71); Maroialicum («gran campo») también es celta, aunque más tarde pasó a llamarse Vicus Aquensis para pasar finalmente a conocerse como Bagnères-deBigorre. En la Notitia Galliarum se hace referencia que la capital de la Bigorra estaba en el castrum Bogorrum (acaso de un antiguo *Begorrum), tal vez ubicado donde está la antigua capital comarcal: Lescar.

- Crebennos: podría estar basado en el celta *kawaro «héroe, campeón», o en * krabi «devoción»; en todo caso, el grupo muta cum liquida no es admisible en protovasco. Constan en todo caso dos tribus de cabarios o cabaros, una en el ámbito centroeuropeo según Pausanias, y la otra en la región de Avignon. Para situarlos, queda la posibilidad de vincular el tribónimo con el nombre del valle 


\section{Nouvelle Revue d'Onomastique $n^{\circ} 54-2012$}

o población que ocupaban, así, se podría localizar en algún valle de la Bigorra ya que el retor bigorrense Axio Paulo se retiró «a su solitaria finca de Crebenno, en un pago sin viñedos, y con una melancólica compañía: no recibe ni un amigo, ni un pariente; él no conversa... sino con las Musas.» (Carta XII de Ausonio); así, parece seguro que esta localidad estuvo en un lugar poco poblado y donde el clima no permitía la viticultura, cosa que encaja perfectamente con algún valle pirenaico: tal vez el de Gripp y aledaños en el caso de que Paulo eligió retirarse en algún valle solitario de su patria bigorrense.

- Garumnos: se les sitúa en la ribera media o superior del río Garona (para Lizop estarían más concretamente en el Valle de Arán), del que tomarían el nombre; su etimología sería céltica, como la villa burgalesa de Garoña, o el oscense Barranco del Garona, o la leonesa Garueña, ya que contendrían un elemento que se correspondería al galo onno «río», si bien otros prefieren ver una protoforma * garun(n)a.

- Convenae y Consoranos: ambos tribónimos son de formación latina. De los topónimos prerromanos del Comminges ya se ha tratado anteriormente, y son los del Couserans los únicos que siguen una pauta diferente a la del resto de Gascuña, ya que si bien por una parte están los típicamente celtolatinos -acum (Bonac, Biac, Aulignac...), los que terminan en -osse y -os son muy escasos, mientras que aparecen otros topónimos acabados en -ein (Augiraein, Illartein, Luentein, Audressein, etc.), lo que permite especular que esta comarca pudo tener un antiguo substrato no vinculado ni con el celta ni con el vascón. En ambas comarcas se han encontrado necrópolis de cromlechs: en Ayer, en SaintLary, en Garin, en Avezac, en Bordes-sur-Rivière, y si se incluye el territorio aranés, en Salardú-Plan de Beret; este tipo de estructuras funerarias (más similares a las de la zona Segre-Cinca que a las del Pirineo Occidental) testimoniarían una diferenciación cultural y social con los habitantes de las llanuras gasconas, pues durante la Edad del Hierro se prefirió el enterramiento de la urna cineraria bajo un gran túmulo de tierra. Recapitulando sobre los aportes étnicos que ha recibido la región, tendríamos que tuvo una fuerte influencia cultural meridional, que el territorio pudo estar dominado por los volcos durante varios siglos tal como se ha tratado con anterioridad, y que en época republicana habría recibido aportes poblacionales de vascones y celtíberos; en conjunto, se hace muy difícil pensar que sea seguro extrapolar la situación lingüística de esta región al resto de la Novempopulania.

- Tolosates: centrados alrededor de su capital, Tolosa. La etimología del topónimo bien puede ser ibérica, ya que se dan topónimos que contienen elementos similares y que se dan en territorio no-indoeuropeo (Tolous, Labitolosa, Baetulo, Tolobis, etc.), o bien puede asimilarse al celta *tullo«agujero» o a otras localidades celtas como Toletum, Tullonium, Tullum, o Tullica. Otros topónimos celtas en la región serían Vernosolis o Vernus Sol > Lavernose, haciendo referencia a alisos o fresnos (*werno-), y Villa Longagisis $>$ Longages conteniendo un elemento celta *longo- «barco ; vaso, cuenco». Se 


\section{El aquitano como lengua céltica (o vascones en Aquitania)}

debe tener en cuenta que esta tribu formaba parte de la más extensa de los volcos, de filiación celta; ocuparon prácticamente todo el Lenguadoc.

Los nombres de las tribus prerromanas no nos darán nunca una certeza sobre si en un determinado territorio se habló una lengua céltica o vascoide según la interpretación que demos al tribónimo, esto se hace patente en como de la antigua tribu ibérica de los ceretanos tenemos hoy en día a los cerdanos catalanoparlantes, mientras que por el norte, de los antiguos consorani, convenae, bigerrones y beneharenses tenemos a los coseranos, los comingenses, los bigorrenses y a los bearneses de habla gascona. Únicamente parece que hayan seguido con la misma lengua los sybulates del Zuberoa, los vellates del Baztan, los campones del Labourd, y los vasco(ne)s de Navarra. Es curioso en todo caso comprobar que allá donde se habla vasco, aun habiendo sido regiones ocupadas por celtas como parecen indicar indicar las etimologías celtas de vellates, campones, bercorates y pimpedunos (y vascones), existen igualmente indicios de topónimos pre-indoeuropeos (Lapurdo, Carasa; Pompaelo, Iturissa, *Ilunberi entre los Vascones) que posibilitan considerar que en esas regiones había una situación de bilingüismo vasco-celta, cosa que no se repite en otras tribus aquitanas, excepto entre convenae e ilurenses.

\section{Topónimos aquitanos medievales y modernos}

Otra clase de prueba toponímica para detectar una antigua presencia céltica la constituye la reconstrucción etimológica de topónimos modernos. Por una parte está la identificación de fundi o villae cuyos propietarios o habitantes prefieren asignarle una derivación céltica -acum equivalente al sufijo -anum usado por los romanos, siendo este un sufijo usado igualmente por los hispanoceltas en Sarnago, Buitrago, Cornago, Cerbiago, Verdiago, Sulago, etc.; tomando así esta referencia, se puede comprobar una presencia celta en todas las regiones gasconas: Lisacq, Commensacq, Ronsac, Donzacq, Pussac, Préchac, Tarsac, Nérac, Calignac, Gensac, Rébénacq, Méracq, Estirac, Talazac, Sénac, Sénacq, Cadéac, Cazac, Biac, y así un largo etcétera, cuya base estaría en antropónimos celtas que no harían sino demostrar que los antropónimos eusquéricos serían muy minoritarios en su conjunto. Es interesante comprobar que esta clase de sufijo celta no se da en el País Vasco Francés ni en el contiguo territorio ilurense. Esta clase de topónimos también nos aportan más información, como la que se desprende de que también muchos propietarios de villa con nombre latino acabaran siendo sufijados con el celtizante -(i)acum: Faustinus $>$ Fustignac, Pompeius $>$ Pompéjac, Gaudius $>$ Gaujacq, Albus $>$ Aubiac, Calvinus $>$ Cauvignac, Salvianus $>$ Sauvignac, Paulinus $>$ Polignac, Paulus $>$ Pauillac, Basilius $>$ Bazillac, Vernus $>$ Bernac, Cornelius $>$ Corneillac, Marcius $>$ Marsac, Pontus $>$ Pontacq, Lancius $>$ Lansac... Igualmente céltico es el sufijo -on usado en Béon, Cadillon, Doazon, Rontigon, Lusson, Maignon, Marsillon, Ponson, Pouillon, y en Sauvagnon, si bien aquí todos muestran una base antroponímica latina y tienen una mayor presencia en el Béarn. Otros topónimos de origen celta a causa de su sufijo son los que contienen -osto- como Gazost, Arbéost, Ardengost, Ansost, Genost, Sost, Assouste (doc. Soste), Ost, Béost, Urost, y Corroux (doc. Corrost), que junto al Bossost aranés tienen una extensión transpirenaica en los aragoneses Binueste, Bagüeste y Las Bellostas; 


\section{Nouvelle Revue d'Onomastique $n^{\circ} 54-2012$}

este grupo Coromines lo compara con el sufijo de los celtas venostes, causostes, vilagostes... apareciendo este sufijo también en el teónimo Alardostus. Se daría incluso el caso de que algunos topónimos con el sufijo latino -anus mostrarían una base antroponímica de tipo celta: Antistus $>$ Antichan, Urdus $>$ Ordan, *Salissius $>$ Salechan, * Samburus $>$ Samuran, Siradus > Siradan, etc. Este comportamiento sólo se puede explicar si se acepta que quienes bautizaron cada población fueron celtas romanizados.

También se deben tener en consideración los numerosos topónimos gascones registrados a partir de la Edad Media y que serían de origen celta (una vez descartado un posible origen en el léxico romance): Arcachon, Arthez, Artagnan, Beccas, Camalès, Durance, Gargas, Lodes, Noë, Nestalas, Palamigny, Plaisance, Ris, Trebons, Vénasque, y varias decenas más. Tampoco resultan demasiado dudosos *Sego-duno («fortalezafuerte»), la actual Sion, *Medio-lanon («mitad-llanura»), la actual Meilhan, Razengues (por contener el celta *ratu, «llano»), *Uxello «altura», que es la actual Eycheil, *Briwa «puente», la actual Labrihe (Brifa en 1295, Briffa en 1322), así como los topónimos que poseen un derivado asimilable al galo -dunum «fortaleza»: Verdun, Saverdun, Dun, Salardú, Tourdun, Gaudun, Calezun, Bezandun, Besaudum, Monlezun (Montelugduno en 1289), etc.

Incluso contando como prerromanos los topónimos de tipo eusquérico, Coromines $(1973,201)$ se hizo una idea aproximada de la situación lingüística de la Aquitania:

J'imagine ainsi la situation linguistique en Aquitaine pendant l'Empire. Dans les vallées pyrénéennes, surtout à l'ouest, à partir du haut Adour ou du Gave de Pau, le Basque est resté maître et sans infiltrations indo-européenes sauf celles d'ordre culturel, mais sans aucune mesure de bilinguisme; dans le reste de la Gascogne des groupes nombreux de langue celtique sont parvenus à consolider des îles linguistiques ou à s'imposer dans certains groupes de la société, peut être bien longtemps avant la conquête romaine, sans parvenir à assimiler tout à fait les populations basco-iberiennes.

Coincidiendo así en cierta medida con Lizop (1931, 108):

Les textes épigraphiques de la région des Ausci et des autres pays de la Gascogne centrale présentent beaucoup plus de noms à physionomie gauloise que ceux de la montagne. L'onomastique aquitaine devient plus rare en se rapprochant du cours moyen et inférieur de la Garonne. La région qui touche immédiatement à la rive gauche du fleuve paraît avoir été, en grande partie, celtisée ainsi que le Bordelais.

\section{Teónimos}

En la comarca de la Comminges, antiguo territorio de los convenios, se constata una aplastante mayoría de dioses no-indoeuropeos (para detalles y bibliografía para cada ND y NP véase GORROCHATEGUI, 1984): Aereda, Ageioni / Ageioni Bassiario, Aherbelste, Alardossi / Alardosto, Andosso, Arardo, Arixo, Artahe / Arte, Astoilunno, Baeserte, Baiase / Baiosi / Beisirisse, Baicorisso / Baigorixo, Bascei, Harausoni, Eberri, Ele, Erdae, Erge, Garre / Garri, Haloassi, Horolati, Idiatte, Ilixoni, Iluni / Ilunni, Iluroni, Ilurberrixo, Ilumber-, Iscitto, Leherenno, Suhugio / Sutugio, Vaxo, Xuban. Los que 


\section{El aquitano como lengua céltica (o vascones en Aquitania)}

pueden ser considerados como indoeuropeos son escasos: Abelioni, Arpenino, Bocco, Borienno, Carpento, Edelati, Exprcennio. En cuanto a la novedad de Oidrito (AE 2004, 911), se debería sumar a los indoeuropeos por contener muta cum liquida.

En el territorio circundante se dan igualmente deidades no indoeuropeas: el novedoso Arsilunno hallado en Argein (Bourdoncle et al.) y Haloisso (Gajan, Ariège, homónimo del conveniano Haloassi) se hallan al este, luego Arhe (Lombez, G), Lurgorr(Sariac-Magnoac, HP) y Herculi Toli Andosso (St-Élix-Theux, G) se hallaron al norte. Al oeste únicamente tenemos Montibus Ageioni ya en la vecina comarca de Bigorra (Baudéan, HP), el cual se relaciona con el Ageioni / Ageioni Bassiario de valles vecinos, por lo cual se ha pensado que representa al genio del monte Bassia (de hecho los hallazgos epigráficos fueron en Rebouc y Asque, poblaciones que están en la falda de dicho monte).

Fuera de esta estrecha área que rodea el Comminges, se hallan dioses indígenas como Axoniebus (Castelnau-Barbarens, en antiguo territorio auscitano), con aspecto indoeuropeo como el del río galo Aisne (antiguo Axona); luego Carpento (Péguillan, HG) es de claro origen celta (*karbant-, carro de guerra», raíz que se reencuentra en el tribónimo de los carpetanos hispanoceltas). Son de adscripción dudosa: Belgoni (Gazost, HP), Laurus(i)ni (Tasque, Gers) por ofrecer la duda de tener una etimología celta o eusquérica (en el primer caso se podría pensar en relacionarlo con el vasco lau(r) «cuatro», mientras que en el segundo supuesto se debería proponer una relación con el protocelta *lawaro- «mucho, exceso»), y Lelhuno (Aire-sur-Adour, antigua Atura, capital de la tribu aturense) cuya aspirada es lo que justifica su inclusión en el grupo de teónimos eusquéricos, pero sin aportar etimología alguna que lo justifique. En todo caso, la aspiración por sí sola no debería ser prueba de eusquerismo, ya que la deidad Lahe (aras en Marignac-Laspeyres, Alan, Castelnau-Picampeau, Francon y Sana), podría relacionarse con el dios Laho de Lugo, como también resultaría problemática la inclusión de nombres aquitanogalos como Valho en Saint-Romain (AE 1945, 73), o Ierha en La Graufesenque (CIL 13, 1552).

Se deben considerar a parte: Larrasoni (con dos inscripciones en Moux, y una en alfabeto griego en Carcasona) por haberse hallado en la vía que une Tolosa con el puerto de Narbona, y poder ser exvotos de comerciantes convenianos; lo mismo ocurriría con Herc(uli) Ilunno Andose (Narbona, CIL 12, 04316), y mucho más cuando se tiene en cuenta que quien ofrece la dedicatoria es un tal Cneo Pompeyo Hyla y que ese nombre nos remite a una persona con posibles conexiones convenianas; también debe tenerse en cuenta que el dios Herauscorritsehe o "verraco rojo» (Tardets-Sorolus) debe excluirse por estar en el actual País Vasco Francés, más exactamente, en la comarca de Soule Zuberoa (en antiguo territorio sibulate).

En vista de la escasez de testimonios, y ante las dudas que generan algunos de ellos, la distribución geográfica de los teónimos no nos sirve para definir el tipo de etnia que le rindió culto, excepto en el caso conveniano, donde parece bastante claro que se practicó una religiosidad con mezcla de dioses eusquéricos y celtas. 
Nouvelle Revue d'Onomastique $n^{\circ} 54-2012$

\section{Antropónimos}

Diferente situación muestra la antroponimia. Entre los convenae con un antropónimo de origen prerromano, este suele ser normalmente pre-indoeuropeo (todos aquellos que Gorrochategui no califica como celtas en su obra de 1984: Andosso, Bambix, Belex, Bihotarris, Bonbelex, Haslcotarris, Harbelex, Lexeia, Ombecco, Osson, Sembexsonis, Sosonnis, etc.); el resto de antropónimos prerromanos, estos suponen una quinta parte del total y son de filiación céltica, si bien se pueden dividir en dos subgrupos. Uno estaría más vinculado con antropónimos hispanoceltas o celtíberos: Aevadia, Britex, Calixsonis, Cassia, Cenuria, Coleia, Coelius, Coerana, Cuctilona, Dannonia, Fafieri, Frontacco, Lanae, Maura, Sennacius, Sennagi, Sennetari, Taure, Tauricus, Teixsossix, Ucoetixix, Vennonius, y Vochio; estos antropónimos celtas no-galos no muestran síntomas de haber sufrido ningún efecto del adstrato vascón. El otro subgrupo está formado por una serie de antropónimos célticos aparentemente galos: Belheiorigis, Bocontiae, Bonnorix, Cintugnati, Cison, Condannossi, Cudueseni, Dunnohorigis (homónimo del Dumnorix lemosín, «Rey de la Oscuridad»), Eppamaigi, Litano, y Sintus. Algunos de estos antropónimos galos son relevantes por mostrar una aparente adaptación a la fonética vascona (aspiración, betacismo, sufijo), cuando no son incluso aparentemente integrados en el mismo dialecto «conveniano" (como podrían ser Cisonten o Cisonbonnis), lo que puede llevar a interpretar esto como que el vascón se impuso como lengua de la mayor parte de los convenae (de hecho algunas inscripciones portan los nombres de lo que podrían ser familias mixtas). Un antropónimo de filiación dudosa es Mandatus, que incluyendo variantes, tiene presencia en Garin, Larboust y Ardiège (aquí con dos casos); la duda procede de que *mando- en protocelta es «caballo», pero existe también como préstamo en vasco (mando), pero con el significado de «asno». Esta concentración de antropónimos de tipo no-indoeuropeo en el Alto Comminges vendría a concordar con la situación toponímica de tal región, así Coromines $(1973,231)$ expresa que "Se verá cómo los nombres aquitanos forman una mayoría compacta; lo que, por sí mismo, nos ayudará a encontrar las etimologías aquitanovascas para aquellos [topónimos] cuya formación habría parecido de otra forma oscura.", mientras que para el Bajo Comminges y Valle de Aran la situación cambia drásticamente: "Il saute aux yeux que plus de $90 \%$ des noms des communes du bas Comminges sont d'origine romane, en partie assez banale, et d'explication claire, et que même dans ce résidu de moins de $10 \%$ beaucoup sont des noms en $-a c$ ou des noms gaulois sans grande originalité." y "[las poblaciones aranesas] ofrecen un número de nombres germánicos, célticos y mismamente romanos relativamente más alto que los de la parte francesa."

La zona circundante con el Comminges tradicional puede ser incluida en el repertorio antroponímico conveniano; esto se puede justificar por el motivo de que siempre que no ha existido una frontera estatal separadora, se han consolidado transferencias de personas desde ámbitos lingüísticos contiguos, lo que hace dudoso el «indigenismo»de aquellos antropónimos que no pertenecen al ámbito lingüístico propio de la región (como ejemplo, véanse los apellidos originariamente aragoneses que hay en pueblos catalanoparlantes del Aragón). Así, en la vecina comarca de Couserans se da una mezcla más equilibrada entre antropónimos vascones y antropónimos celtas o galos: 


\section{El aquitano como lengua céltica (o vascones en Aquitania)}

Hannarro, Sembexonis, Bontos-, Sembetar, Neureseni, Hauteten e Ittixonis por una parte; Tottonis, Solimari, Tauricus, Conditus, Congi, Donni, Dannorigis, Aldeni, Dannoesa, Toutannorigis, Dannoni y Dunomagius por la otra, siendo además todos estos antropónimos encontrados en poblaciones bastante cercanas a las convenianas (Arrien-enBethmale, Gajan y Saint-Lizier). Esta mezcolanza también se repite con los teónimos, pues coexisten a la vez los celtas Andei (Caumont) y Minerva Belisamae (Saint-Lizier) con los eusquéricos Arsilunno y Haloisso.

En la franja que limita Comminges por el norte tenemos los nombres de Sembi (StElix-Theux, G.), Baiexe- (Saramon, G.), y tal vez Semperri (Sariac-Magnoac, G.), los cuales refuerzan una visión vascona de esta estrecha franja septentrional, visión reforzada por los hallazgos de teónimos eusquéricos como Herculi Toli Andosso, Arhe o Lurgorr-. Esta franja pudo ser igualmente colonizada por vascones al estar precisamente ahí la Belsino que antes hemos tratado.

En cuanto a la zona circundante que limita por el noreste de los convenae, los antropónimos son casi todos celtas: Axsedo, Cloepius, acaso Semperrus (Cazères, HG), Cassili, Dunnohoxis (Martres-Toulousane, HG), Aconi (Palaminy, HG), Cassidanni, Soliti (Saint-Cizy, HG - antigua Aquae Siccae), y tal vez también Boncoxsi (Montbéraud, $\mathrm{HG}$ ), por lo que la frontera social y/o étnica parece bastante fijada con sus vecinos célticos de la tribu de volcos tectósagos (con capital en Tolosa).

Hacia el oeste, en la vecina comarca de la Bigorra, todos los antropónimos prerromanos resultan ser eusquéricos: Bihossi (en Barbazan-Dessus, pueblo situado entre Tarbes y Cieutat/Bigarra, la primera capital de los biguerrones), Bonxi (Lourdes, HP), y Sembeddonnis (Bagneres-de-Bigorre, la antigua Vicus Aquensis, a pocos kilómetros de donde se encontró el teónimo Montibus Ageioni). Como Tolomeo reparte el Pirineo aquitano entre tarbelos y convenos, hace muy posible que el vecino territorio de los bigerrones hubiese sido asignado a los convenios tras conquistar Roma la Bigorra, con la intención de asegurarse el control y la romanización de un territorio montañoso de escaso interés para el Imperio, lo que permitiría justificar la presencia de personas con nombres de tipo eusquérico en esa comarca.

Fuera de los límites de los biguerrones y de los convenae y de sus respectivas zonas circundantes, la situación es la contraria, siendo claramente mayoritario el uso de antropónimos celtas sobre los eusquéricos, tanto en ambientes urbanos como rurales: Coeranus, Comba-, Fronta-, Cloepiae, Attaiorig-, Bersegi, Dunaio, Dunai, Orcuari, Toutaronia, Matico (todos en Auch, antigua Augusta Auscorum), Cambuxae (Duran, a muy poca distancia de Auch), Cahenna, Ulohossi, Sambili, Vinusius (Lasséran, cerca de Auch), Taurico, Sambo (Barran, Gers), Illai, Saledunae (Nux, G.), Karinae (Marcet, Haute-Garonne), Cerdoni, Damcixa (Eauze, antigua Elusa), Accaten, Condai (Cieutat, a 2 kilómetros de Eauze), Cenialinis (Montferrand-Savès, G.), Aedunniae (Saint-Amand, G.), Camuli, Comenuae, Donnia, Turran- (Lectoure), Brittula (Peyrebert, G.), Aucasi, Ambili (Saint-Puy, G.), Soemuti (Gimont, G.), y Sarmestela (Castet-Arrouy, G.). También se podría incluir el hispanocelta Ambaico, en caso de ser una dedicatoria de un íbero ya que tal nombre está escrito en caracteres y términos ibéricos (anbaikaR) sobre una copa de plata que fue hallada en un túmulo funerario de Aubagnan. Otros aquitanos con nombre celta fueron el rey sotiate Adiatunnus y el jinete Pisón según relata Julio César (B.G. III, 
22 y IV, 12), quedando registrado igualmente el monarca en monedas sotiates: $R e x$ Adietuanus. De igual manera se debería tener en cuenta un antropónimo de tipo celta posterior al trabajo recopilatorio de Gorrochategui Belessimae (Auch, CIL 13, 452). En conjunto, no se aprecia ningún efecto de substrato eusquérico sobre estos nombres excepto tal vez en el de Bocontia, Cahenna, Ulohossi y Adehio, por lo que la situación lingüística parecería la contraria a la observada en el Comminges, que el celta fuese la lengua popular de Aquitania y el eusquérico o el íbero la lengua de una «casta comercial» tal como parece suceder en la Narbonense con los teónimos de tipo eusquérico antes analizados.

Luego, en esta misma zona, los antropónimos con mayor o menor seguridad sobre su eusquerismo (o iberismo) se restringen casi exclusivamente al ámbito urbano: Torsteginno, Belexeia, Tarlebissi, Holox-, Laureia, Osaherr- (Auch), Talsconis, Tarros (Eauze), Andosteni (Tarbes, AE 1997, 1125), Titiluxsae, Talseia (Gimont, antigua Casinomagus, junto al río Gimone y en medio de la ruta que une Tolosa y Auch); para las zonas aparentemente no urbanas únicamente tenemos Laurco (hallada en Touget, en la antigua vía entre Casinomagus y Sarralis), y acaso Ahoissi (Nux, próxima a Auch). Son de asignación dudosa Annereni (Muret, HG) e Igilli (Auch), ya que el primero puede asimilarse tanto con el vasco andere «mujer», como con la misma palabra celta responsable del préstamo y que fue usada igualmente en antropónimos celtas (Anderenus en Medina del Campo, Hep-04, 955, o C. Licinus Andero en Colombara, en el norte de Italia, $A E$ 1994, 671); en cuanto al segundo, Igilli, parece contener el mismo formante que los celtas Cuigilla, Romogillia y Torogilla de otras regiones. En cuanto a Adehio, Adei y Harbelestegis (Albret, Lot et Garonne), al tener estas personas el oficio de structor según la lápida que encargaron, implicaría una alta posibilidad de que fuesen personas foráneas (fuese como comerciantes, jefes de obra, o escultores). En cuanto a Bortossi (Eauze), al ser hija de un legionario de la Legio VI Victrix hispana no debería ser tenida en cuenta por motivos evidentes.

Se deberían incluir (y contabilizar) los antropónimos celtolatinos que Gorrochategui rechazó en 1985 a causa de querer primar el hipotético substrato prerromano noindoeuropeo, procedimiento que como se puede observar en este trabajo, no estaría justificado: así se pueden añadir entonces Lanipendia (Auch), Cominia (Saint-Girons), y Attius con sus derivados (dos Attius a Aire-sur-l'Adour, dos Atticus en Saint-Beat, otros dos Atticus en Valcabrere, un Attixsis en Genos, y una Attia en Ardiège). Un repaso y actualización de la onomástica prerromana aquitana desde una perspectiva celtista, que ha sido por demasiado tiempo rechazada y abandonada, debería añadir más casos similares.

Si luego incluimos los antropónimos hallados en inscripciones de la zona gala de Burdeos (y que fueron excluidos en el trabajo de Gorrochategui), la presencia celta es tal que hasta merecería un análisis detallado, sobretodo porque algunos muestran aspectos fonéticos «aquitanos»: Adnameti, Aduorix, Atioxtus, Taluppa, Sintaugus, Senondae, Solini, Aulici, Critoni, Craxxillu, Bitudaga, Pixticenus, Penticeiuve, Laguaudi, Ligaun, Caunus, Cintugeni, Cintugnato, Cintonis, Senodonnae, Bloxi, Sammunicus, Samoceni, Comnitsiae, Congonnetaci, Coriosolis, Icae, Ateulae, Escingus, Divogena, Ogilolus, Nemetocenae, Toceti, Dagobius, Batrusconi, Tasgilli, Tesconis, Noniconius, Horcolate, Soriolitonis, Conisovini, Andelipae, Cantoseni, Belest-, y un largo etcétera. Algunos de 


\section{El aquitano como lengua céltica (o vascones en Aquitania)}

estos nombres presentan ciertos rasgos pretendidamente aquitanos (eusquéricos) como el sufijo $-c o(n)$, la fricativa post-alveolar sorda $(-x x-)$, o la aspiración, posibilitando esto pensar que estos rasgos junto a otros que se han venido definiendo como «aquitanos» sean en verdad propios también del aquitanocelta, por lo que ciertos antropónimos eusquéricos deberían ser analizados otra vez para garantizar su filiación vascoide.

Incluso apartando los antropónimos bituriges del conjunto aquitano (y por supuesto los presentes en la región de Lugdunum Convenarum y áreas limítrofes), los antropónimos celtas superan apabullantemente a los eusquéricos, mucho más cuando se añaden aquellos antropónimos que han quedado fosilizados en topónimos del tipo -acum, puesto que esta clase de testimonios tiene el mismo valor que los antropónimos indígenas hallados en lápidas votivas o funerarias; si exponemos esto en números quedaría una relación de 13 antropónimos eusquéricos posibles por 48 de celtas hallados en inscripciones de la Novempopulania, a los que pueden ser sumados 12 o 13 decenas de antropónimos celtas conservados en topónimos, con lo cual tendríamos una relación bruta de 1 a 13, una relación suficientemente relevante como para poner en duda el eusquerismo del aquitano.

Es una lástima que no se tengan más datos sobre el origen exacto de los aquitanos que vivieron fuera de su país y que conservaban un nombre prerromano, lo mismo que hasta ahora no hayan sido tomados en consideración en trabajos anteriores; se trata de los nombres mencionados fundamentalmente en dedicatorias de soldados aquitanos repartidos por todo el Imperio Romano: los convenios (O)rcoeta y (B)ihonis (AE 2004, 674) no suponen demasiado problema para situarlos en su contexto, pero los aquitanos (latu sensu) Tabusi (CIL X, 7596), Tarcho y Tarbunnis (CIL III, 2053), Burrius y Betuloni (CIL III, 9760), Pardalas (CIL VI, 2131), y Sentiu(s) (CIL XIII, 6658) son problemáticos. También deberían analizarse los topónimos que constan como origen de estas personas: Camui Tarpolie (CIL III, 2053), Saldas (CIL XIII, 6620), y Thaenis (CIL XIII, 11782). Todos estos antropónimos y topónimos necesitarían de un estudio etimológico y comparativista detallado ya que parecen ocultar fonemas interesantes para desvelar evoluciones y correspondencias lingüísticas hasta ahora poco claras. Mención aparte merecen las placas votivas de plata con antropónimos eusquéricos encontradas en la localidad alemana de Hagenbach, ya que ofrecen igualmente la duda de cual debe ser la comarca de origen (o donde fueron robadas), y por lo tanto, no nos sirven para el tema tratado aquí.

Una palabra aquitana: solduri

Los soldurios son mencionados en el el libro tercero que Julio César dedicó a las guerras de conquista de la Galia (s. 21 y 22), y es así según César cómo llamaban los sotiates a los escoltas personales del rey Adiatumno; una clase de escoltas o soldados que prometían morir si su líder perdía la vida en batalla a cambio de compartir entre todos las ganancias de sus victorias, se trataba pues de la misma devotio que practicaban celtíberos e íberos. Esta sería la única palabra que quedaría del antiguo aquitano, y aun a riesgo de poder ser un préstamo o ser una palabra usada por una élite de origen alóctono, saber su etimología nos puede hacer decidir por una filiación céltica o eusquérica del idioma. En el 


\section{Nouvelle Revue d'Onomastique $n^{\circ} 54-2012$}

vasco, se puede aportar como posibles palabras relacionadas olde «arranque impetuoso ; invasión, gran cantidad», oldar «acometida, embestida, ofensiva ; valor, esfuerzo, ánimo», y oldarkoi «audaz, osado», pero una pérdida de sibilante sólo se da en vasco si existe disimilación, caso que no se pudo dar en estas palabras, y además, podría ser que olde sea una variante de uhalde «avenida, crecida de agua», palabra compuesta por $u r$ «agua» y alde «parte». El celta en cambio es más productivo si partimos de la variante siloduri que registra Ateneo de Naucratis (Deipnosofistas VI, 54) y que copió de Nicolao de Damasco; según él, siloduri se traducía al griego como «ligado, vinculado, obligado por promesa ; voto», lo que sería apto para poder ser comparado con raíces celtas como *s-lo «semilla, descendencia», de donde deriva el antiguo irlandés si'l «semilla», el galo silo «descendencia, linaje», y el galés hil «raza, linaje», o como el galo selo «tomar, coger», o como *oyto «voto, promesa», de donde proviene el antiguo irlandés oeth y el galo oito, o como *odbo «nudo», o como el galo duro, cognado del irlandés dur «duro» del galés dir «fuerza» y del bretón dir «acero», etc. que hacen más verosímil que la palabra aquitana esté formada por cognados del galo selo «tomar» y oito «voto»:

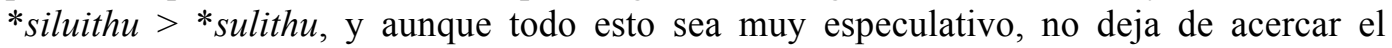
aquitanismo al celta.

\section{Supervivencias aquitanas y vasconas en el gascón}

Si aceptamos que el aquitano fue lengua céltica, entonces habría que considerar el hipotético léxico aquitanovasco como producto de unos préstamos del vascón al latín regional: abarka > abarco «sandalia», *arraNo > arrianh «buitre», *anabi > avajon «endrina», *tista > tisto «cesto», txingar > chingarro «manteca», askarra > escarruè «árce», lerratu > eslerrà «resbalar», lakarra > lacàrro «pendiente rocosa», estalbe > estaubià «ahorrar», anbula > ambùro «asfodelo», neska > nesco «chica», mantzur > mansurru «tacirturno», zamar > samarre «saca para dormir del pastor», etc., palabras que en su gran mayoría están estrechamente vinculadas a un entorno pastoril, típico de los habitantes prerromanos del Saltus Vasconum.

La intrusión de este tipo de léxico vascoide se confirma si analizamos las supuestas supervivencias aquitanas, así, si por una parte tenemos palabras de origen no-indoeuropeo con -rd- como gabardè («escaramujo», que junto al aragonés gabardera se corresponde al vasco gaparr-, zarza»), e isard («rebeco», cognado del aragonés sarrio, sisardo); por la otra parte tenemos una abundancia de palabras en que la misma rótica vasca -rr- ha quedado igual en sigorre (un tipo de junco, que junto al aragonés sigüerre, eléboro, se vincula al vasco zigorr-, conservando ambos -g- intervocálica...); gabarro «aulaga»; arriành «buitre» que se relaciona con el vasco arrano < *arraNo «águila»; lapàrru, labàr, lapàrro «piojo de los animales», que sería préstamo del vasco lapar (la oclusiva queda sin sonorizar además); mar, màrru, màrri, marron, mardà, mardanh «carnero» se corresponden al aragonés mardán y al vasco marro; capàrro, gabar "garrapata» se compara con el aragonés caparra y con el vasco kaparr-; biscàrro «viga principal», se corresponde al aragonés bizcarrera y al vasco bizkarr- «lomo, dorso»; samarre «chaleco de piel de los pastores» tiene relación con el aragonés zamarra y el vasco zamarr-; chingarro «trozo de manteca», que junto al aragonés chingarra «idem» $\mathrm{y}$ al navarro 


\section{El aquitano como lengua céltica (o vascones en Aquitania)}

chingarra «manteca» se relacionan con el vasco txingarr-; así mismo eslarrà «resbalar» con el vasco lerratu; mâ esquèrro «mano izquierda» con el vasco ezkerr-, etc.

Por otra parte, si aceptamos una ocupación/migración de gentes vascónicas caracterizadas por un modo de vida trashumante y pastoril tal como se desprende de los escritos medievales arriba citados, podemos explicar también la anómala presencia de iberorromanismos en Gascuña, ya que estos emigrantes pudieron llegar a la zona junto a vascones ya romanzados, o sea, gentes que hablarían el dialecto iberorromano en el que se basó más tarde el proto-navarro-aragonés. Esta hipótesis explicaría de manera satisfactoria la presencia de léxico iberorrománico en una región que en principio debería ser exclusivamente galorromana tanto por su posición geográfica como por el lapso de tiempo que media entre la ocupación y colonización romana de tales territorios (se piensa que el dialecto latín hablado en la Galia tenía y tiene una buena parte del léxico mudado a causa de que los colonos romanos que llegaron a la región hablaban ya un latín algo diferente del que hablaban los colonos que ocuparon Hispania). De igual manera, se podría atribuir a este adstrato protorromance características fonéticas como el betacismo, el paso de -MB- a -m- (presente en el aragonés, el castellano y el vasco), así como el cambio -LL- > -r-, atestiguado en topónimos aragoneses y también en el mismo vasco cuando no hay geminación (además Rohfls relacionó igualmente este rasgo con la palatalización existente castellano y catalán de -LL-). En cuanto al léxico, se puede ver otra vez una gran presencia de términos relacionados sobretodo con el ámbito del pastoreo y la horticultura, así algunos ejemplos de voces aragonesas o navarroaragonesas con cognado gascón son: andana «rejado de ramas para secar la fruta al sol), acerón «arce», aplegar «reunir», aro «madera para hacer el queso», arroyo (del latín hispánico arrugia), baranda, bucardo «un tipo de cabra salvaje», broxa «bruja», burguil «palo de pajar o henar», cameña, cingla «cornisa», conchesta «nieve congestionada», corral, cubilar, cueva, cuna, cherbigadero «precipicio», estonda «rato» (palabra de origen godo), grieta, farto, fayo (género masculino), fita «piedra de linde», ladrar, lenera «bloque de piedra lisa», mallata «majada», mallo «roquedal», meco «ternero», meyo «mellizo», mostachera «mostajo», ant. navallya «navaja», pardina «lugar inculto para pastar», pesebre, pierna, pleta «corral para ovejas», pocilgalporciga, purna «chispa», serrón «zurrón», sobago «lugar privado de sol», tasca «hierba», texo, tierco, toba «gruta», truco «golpe», etc. En fin, una intrusión de vascones y de navarros en la Galia merovingia explicaría también la presencia de vocabulario iberorrománico en el Macizo Central (zona muy apta para desarrollar una economía pastoril), así como la existencia de topónimos de tipo -os al norte del río Garona, en una zona donde la presencia de tribus galas está más que asegurada: Carcòs, Carròs, Libòs, Moulòs, Picòs, Bardos, Bellos, Garosse, Gueyrosse, Marosse, Sambosse, etc. ${ }^{3}$

Sobre las verdaderas supervivencias del substrato aquitano (como lengua céltica), estas quedarían en cierto modo disimuladas por la influencia del vecino dialecto lenguadociano, cuyo substrato parece ser en gran parte de tipo galo, si bien algunas supervivencias célticas sí que se pueden aducir al no tener una continuidad en

3 Tampoco todos los topónimos gascones acabados en -os deberían adjudicarse automáticamente al superestrato vascón: p.e. Argelos y Bernos pueden hacer referencia a lugares argilosos y alisosos. 
Nouvelle Revue d'Onomastique n $54-2012$

lenguadociano:

- jaubo «aulaga» del galo *yowga, cognado del francés ajonc.

- padàrna «gran rendija en un leño», desde el galo darnom «partido».

- padoénh «pastos», del galo *patu «alimento».

- garuno «río», desde el celta *garun(n)a, de donde procede precisamente el Garona, además del provenzal garuno «canal de secado», y el castellano guareña «prado en la que abundan los regatos o las fuentes ; ribera, arroyo ; charca ; cahozo, prado en que abundan los regatos y cahozos».

- nèsta «torrente, arroyo»

- briu «corriente de agua», del galo *briwos

- cassourre «agalla de roble» (Aspe), des de la raíz céltica *kassos «roble».

- léo, lédo, leyo, lio «trineo, narria» (y tal vez lèbio, lùbio y libia) proceden del celta $*(s) l e d a$ «trineo, narria», con derivados en savoyano «luge, glosado como sludia en el siglo IX), el roergués leudo, leuzo, el piemontés leza, zlüxa, el ligur lèsa, el lombardo slita, liza, el véneto lissa, y en el irlandés luad- «arrastrar».

- taram «trueno», procedente del celta *taranus.

- gao, gabe, gàbat «río» y gabe «torrente» son cognados del provenzal gaudre «barranco, torrente», del piemontés gòia «pequeña laguna», del dolomítico gao «río», del friuliano gavin "pequeña laguna», y del istriota gavuso «pantano», palabras que a su vez se pueden vincular con el celta *wabero «río», de donde procede el irlandés gover y el bretón gouver.

De todas formas, habría una cantidad considerable de palabras de posible origen prerromano exclusivas del dominio gascón, pero que no resultan fáciles de emparentar ni con el vasco ni con el celta: asco «avalancha», baspano «párpado», bastë «aulaga», braude «lodo», briòc «buitre», chirpu «sapo», chòc «pequeño», craste «arroyo», crum «nube espesa», dralho «barro líquido», drusc «orujo de las uvas», esquiá «festuca punzante», garbistre «calostro», gàret «hondonada, barranco», garlàs «manantial», glabia «muela», nhaule «negro», guimp «agrio», hamà «ladrar», hurc «bosque», tuch «maxilar», etc.

\section{Conclusiones}

Los datos obtenidos de la toponimia antigua apuntarían a que únicamente pueden ser considerados con certeza como eusquéricos los tribónimos y topónimos que han aparecido bien en áreas con presencia vasca en la actualidad (sibylates, Carasa, Lapurdum), bien en una área contigua (Aspaluci e Iluro, siendo ambas plazas situadas en la importante vía que une Zaragoza y Burdeos por Jaca y Somport), o bien por estar en zona conveniana; el resto de topónimos se pueden adscribir en mayor o menor medida al celta. Esta situación en su conjunto nos plantea que los topónimos eusquéricos no son representativos del ámbito étnico aquitano, menos aún si consideramos que la Aquitania de César no contaba entonces con las comarcas de Comminges y Couserans, ya que por aquel entonces aún estaban bajo administración narbonense. En todo caso, si lo 


\section{El aquitano como lengua céltica (o vascones en Aquitania)}

desconociéramos todo sobre Gascuña excepto sus topónimos antiguos, esta región pasaría por una región más del orbe celta, tal como si del Nórico o de la Britania se tratase. Se da además el caso de que existió una muy posible trasplantación de topónimos por parte de los nuevos colonos vascos y celtíberos: Belsinon y Calagurris tienen sus homófonas en la ribera del Ebro, en una zona que hizo precisamente frontera entre estas dos étnias.

En cuanto a los teónimos de tipo eusquérico, vemos que estos se restringen a las zona vascoparlante y a la zona conveniana (poblados cercanos incluidos), por lo tanto, este tipo de onomástica no es tan determinante como para pretender que el aquitano fuese una lengua emparentada con el vasco y no con las lenguas célticas.

Los antropónimos, siempre más móviles, plantean igualmente una preeminencia celta en el llano, mientras que son efectivamente los eusquéricos los que se concentran en la montaña, siendo esto especialmente válido para la zona conveniana (y área circundante), y la comarca bigorrense, si bien la situación sociopolítica de esta comarca debió ser bastante particular ya que si por una parte los bigorrianos que conocemos portan nombres eusquéricos, sus ciudades en cambio portan nombres celtas (Bonxi en Noviodunum, Sembeddonis en Maroialicum, Bihossi en Tarodunum), estado que sea lo que pretenda representar, sí que debió haber provocado que los biguerrones fuesen vistos por los romanos como un tipo de aquitanos con ciertos rasgos vascones, si bien lo único que ha trascendido de ellos no está relacionado con la lengua, sino que vestían diferente del resto de los aquitanos pues usaban vestiduras hechas de vellón.

De todas maneras, hay presencia de antropónimos eusquéricos en aquellas ciudades de la llanura gascona cercanas al Comminges: Augusta Auscorum, Elusa, Casinomagus, y posibles puestos de tránsito; una situación o mapa que nos remite más a una presencia fundamentada en el comercio que a cualquier otra posibilidad, posibilidad que nos vendría confirmada por la distribución misma de teónimos vascones en la provincia narbonense.

De todas estas informaciones, sólo se pueden extraer dos conclusiones posibles sobre el parentesco lingüístico del aquitano:

- El aquitano estaba emparentado con el vasco, pero únicamente lo conservaban a la llegada de los romanos gente de extracción social humilde en una situación de diglosia y aculturación previa en la que una aristocracia o élite celtoparlante detentaría el poder, lo que explicaría la menor presencia de testimonios eusquéricos (tal como se ha propuesto para caristios y bárdulos en el actual País Vasco). No hay pruebas suficientemente consistentes como para defender la validez de este supuesto una vez conocemos la trayectoria étnica de la región; además, la primera presencia celta segura estaría atestiguada por la presencia de la cultura de los Campos de Urnas a partir de la transición Bronce/Hierro, lo que haría que el bilingüismo habría prevalecido durante los siete siglos que mediaron hasta la llegada de los romanos, por contra, la experiencia histórica determina más bien que las sociedades estructuradas mediante tribus son incapaces de hacer perdurar situaciones duraderas de bilingüismo, de hecho, hay más conocimiento de sustituciones lingüísticas rápidas (tribus britonas por sajones, jutos y anglos; tribus tracias por tribus eslavas, etc.). 


\title{
Nouvelle Revue d'Onomastique $n^{\circ} 54-2012$
}

- El aquitano fue una lengua celta pero diferente del galo, permitiendo esta segunda posibilidad explicar dos "extrañas" paradojas como que fuesen los cántabros hispanoceltas, y no otros (vascones o galos), quienes acudieran en ayuda militar de los aquitanos para combatir a los romanos (De Bello Gallico, III, 26), o que muchos tribónimos aquitanos compartan el sufijo de pertinencia ate con tribus celtas y celtoligures (belgites, ilvates, hercates, hercuniates, cornacates, deciates, genuates, tolosates, dexivates, quariates, nantuates, carnutes, atrebates, arabiates, serretes, etc.). De todas maneras, y a la vista de los datos aportados, negar que el celta fuese autóctono en la antigua Novempopulania, conllevaría un gran esfuerzo en justificar esta evidente y masiva presencia de gentes indoeuropeas, siendo por lo contrario más fácil justificar las presencia de gentes no-indoeuropeas en determinadas regiones aquitanas como el resultado de una colonización histórica.

Esta última posibilidad también permitiría reinterpretar el sentido de dos afirmaciones de Estrabón (Geog. IV, 1-2) sobre los aquitanos y sus vecinos:

\begin{abstract}
Algunos, como se sabe, han dividido [la Galia] en tres partes, llamando a sus habitantes aquitanos, belgas y celtas. Los aquitanos, dicen, son los más diferentes, no solo respeto a su lenguaje sino también por su físico ya que es más semejante al de los íberos que al de los galos; ciertamente el resto de los habitantes tienen una apariencia gala, si bien no todos ellos hablan la misma lengua puesto que algunos tienen pequeñas variaciones en sus lenguajes. [...] Ya que, por decirlo de algún modo, los aquitanos difieren de los galos en la constitución de sus cuerpos así como en el habla, que es como decir que se parecen más a los íberos.
\end{abstract}

Estrabón separa lingüísticamente a los aquitanos de galos y belgas, los cuales se diferenciaban por leves diferencias dialectales (en realidad se diferenciaban más por razones culturales y etnogenéticas que por otras causas); en cambio, cuando dice que los aquitanos se parecen en lenguaje a los íberos, debemos preguntarnos si se refiere a los íberos como etnia (cuya lengua era no indoeuropea), o bien se refería a los íberos como al conjunto de los hispanos, cuyas hablas más extendidas eran además del íbero, el celtíbero, el para-celta de la zona occidental, y los poco estudiados dialectos hispanoceltas del centro y norte peninsular. A este planteamiento habría que añadir la afirmación de Julio César de que estas diferencias afectaban tanto a aquitanos como a galos como a belgas: «Estas naciones difieren entre ellas por la lengua, las instituciones y las leyes» (De Bello Gallico I, 1), por lo que este punto de vista no niega tan contundentemente que los aquitanos pertenecieran a la subfamilia céltica, mucho menos cuando leemos en Estrabón qué diferencias lingüísticas había en Hispania:

Los turdetanos están considerados como los más sabios entre los iberos; usan un alfabeto con el cual han mantenido registros de su antigua historia, poemas, y leyes escritas en verso desde hace 6000 años según aseveran. También los otros íberos usan un alfabeto, pero ni es el mismo ni tiene las mismas letras, ya que su lengua tampoco es una ni la misma. 


\section{El aquitano como lengua céltica (o vascones en Aquitania)}

Lo que sabemos sobre la epigrafía paleohispánica es que se usaron varios registros: el sud-lusitano en el sur de Portugal, el alefato fenicio en la Baja Andalucía, el semisilabario del sudeste en la Alta Andalucia y Murcia, el alfabeto griego (para escribir ibérico en Alicante principalmente), y luego se usó el semisilabario levantino en resto del País Valenciano, Cataluña, Aragón y Navarra; los celtíberos, por su parte, usaron una variante del semisilabario levantino. Como se ve, existe la duda a qué íberos hay que relacionar los aquitanos. Aún se relativiza más la diferencia entre aquitanos y galos si leemos la Historia de Roma (libro XV, 11) de Amiano Marcelino, en una época, el siglo $\mathrm{V}$, en la que ya se conocerían mejor los pueblos conquistados por Roma:

Parece ser que, en tiempos antiguos, cuando la Galia bárbara nos era absolutamente desconocida, la región estaba repartida entre tres razas bien distintas: los celtas o galos, los aquitanos, y los belgas; las tres diferentes en lengua, costumbres y gobierno. Entre los aquitanos y los celtas o galos, el límite natural es el Garona, río que nace en los Pirineos, y baña numerosas ciudades antes de perderse en el Océano.

En definitiva, pensar en un celtismo para el aquitano evitaría suponer que Dion Casio cometió un error de percepción al decir:

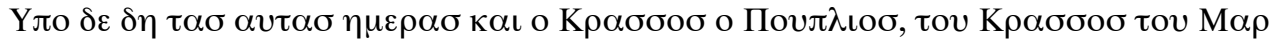

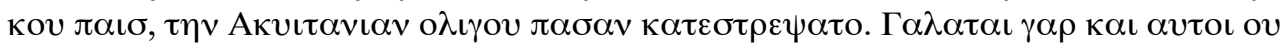

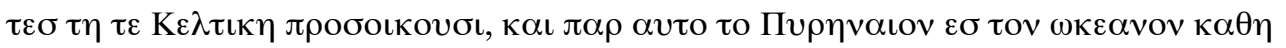
кобเv.

Al mismo tiempo, Publio Craso, el hijo de Marco Craso, subyugó casi toda la Aquitania. La gente de esta región, que son igualmente galos, habitan los confines de la Céltica [Galia] extendiéndose a lo largo de los Pirineos hasta el océano. (Historia de Roma, XXXIX, 46)

Es reconociendo un celtismo para el aquitano lo que resolvería la paradoja que supondría que un galo pudiera tener la opción de expresarse en su lengua nativa... ante una audiencia de monjes aquitanos, según el testimonio aportado por el también aquitano Sulpicio Severo a principios del siglo V (Dialogos I, 26):

- Ciertamente, respondió Gallus, como quiera que sea débil para un fardo tan pesado, ahora, entusiasmado por los ejemplos de obediencia que nos a contado Postumianus, no iba a rehusar la carga que me habéis impuesto; pero, como pienso que yo, un galo, debe hablar delante de aquitanos, temo ofender vuestras delicadas orejas por causa de mi poco cuidadosa lengua, escuchadme entonces como un hombre grosero, simple y sin elegancia en su lenguaje; pues si me tenéis por ser discípulo de Martín, permitidme con su ejemplo evitar un estilo vanamente elegante y florido.

- Habla celta o galo si lo prefieres mejor, le responde Postumianus, pero al menos háblanos de Martín; en cuanto a mí, pienso que, incluso que fueras mudo, no te faltarían palabras elocuentes para hablarnos de Martín: ¿acaso la lengua de Zacarías no se desató para pronunciar el nombre de Juan? En todo caso, eres un hombre instruido y eres versado en el arte, pero te excusas de tu inhabilidad porque estás lleno de elocuencia: un monje no puede 


\section{Nouvelle Revue d'Onomastique n $54-2012$}

ser tan hábil, ni un galo tan astuto.

Tal vez la mejor solución para resolver definitivamente si el aquitano era eusquérico o céltico, sería aceptar los hidrónimos como el tipo de topónimo más conservador por perdurar más en el tiempo, con lo cual podríamos observar una importante presencia de nombres celtizantes (o de dudoso eusquerismo por lo menos) de los actuales ríos gascones: Gimone, Adour, Gers, Touch, Save, Cédon, Arçon, Izaute, Auronce, Rhône, Lizon, Sousson, Ouzon, Lambon, Nadesse, Auloue, Auzoue, Midour, Bergon, Ciron, Estrigon, Onesse, Camezon, Noue, Toran, Arac, etc., y que contrastan con una menor presencia de hidrónimos que pueden interpretarse con el vasco (además de poder ser posteriores a las razias vasconas): Arrats, Ousse, Luzoué, Osse, Lez, Ger, Arbas, Aspe..., y que mayormente se encuentran en la zona pirenaica.

Todas estas evidencias, de confirmar que la lengua indígena de la Novempopulania fue céltica, provocarían un necesario cambio de conceptos como que por «aquitano»se entendiera la lengua celta propia de la región, y cuando se tratara con restos onomásticos vascoides anteriores a las razias vasconas, se debería usar el nombre de «eusquéricos», «vascones norpirenaicos», o más especificamente, «convenianos». La existencia de un dialecto «conveniano» estaría asegurada por dos rasgos lingüísticos que lo diferenciarían del vascón de Navarra: el mantenimiento del grupo -mb- y la conservación de /o/, características que pueden extraerse de comparar el elemento onomástico conveniano Ombe- con el vascón Umme- de Lerga (Navarra), un elemento que ha sido identificado con el actual ume vasco «cría»; se trataría pues, de dos diferencias provocadas seguramente por una mera deriva dialectal, consecuencia atribuible a los tres o cuatro siglos de separación que median entre el asentamiento pompeyano y el momento en que se grabaron los nombres indígenas que aparecen en lápidas votivas y funerarias.

En fin, una vez que se ha expuesto la problemática que implica suponer sin restricción alguna que todos los teónimos, antropónimos y topónimos aquitanos de tipo eusquérico han de ser representantes de un estadio etnocultural prerromano, y después de constatar además la importancia que tuvo la lengua celta en Aquitania (hasta el punto de poderse hipotetizar que el aquitano fuese una lengua céltica), únicamente queda una solución posible a esta problemática y es la que nos pueda ofrecer la arqueología; así, tras intentar relacionar la cultura material aquitana con las vecinas, se observa que durante la Edad del Bronce la Gascuña participó del ámbito cultural atlántico, cultura extendida por zonas como el norte de Francia o el Benelux, quedado por lo tanto relegadas las antiguas tradiciones megalíticas a algunos valles pirenaicos del Couserans y Comminges; será durante el inicio de la Edad del Hierro cuando se constatará en toda la región conexiones culturales tanto centroeuropeas (urnas cinerarias depositadas bajo un túmulo de tierra, encastillamiento de la población) ${ }^{4}$ como meridionales (broches de cinturón del tipo «Acebuchal», torques, lanzas, espirales de bronce, túmulos de tierra conteniendo múltiples incineraciones, tipos cerámicos, etc.), cuando no es sino la misma Aquitania un foco cultural, tal como acontece con el tipo de espada «Echauri», tipología

4 Conexiones no sólo culturales sino también étnicas, así en Coffin (1986, 45): "Au début de l'âge de Fer se met en place un élément brachycéphale de haute stature qui modifie profondément le fond ancien." 


\section{El aquitano como lengua céltica (o vascones en Aquitania)}

que adoptará la región que más tarde se iba a conocer como Celtiberia (GARCÍA, 2006).

\section{Bibliografía}

AMELA VALVERDE, LUÍS:

- (2000): «Las ciudades fundadas por Pompeyo Magno en Occidente: Pompaelo, Lugdunum Convenarum y Gerunda», Polis, 12, pp. 7-41.

- (2002): Las clientelas de Cneo Pompeyo Magno en Hispania, Col·lecció Instrumenta, 13

ARMENDÁRIZ MARTIJA, JAVIER (2009): «La ordenación del territorio vascón en la Edad del Hierro», en Los vascones de las fuentes antiguas, Javier Andreu Pintado (ed.); Col.lecció Instrumenta, 32, pp. 303-338

ARTICA RUBIO, EDUARDO (2009): «Algunos apuntes sobre los Vascones en la guerra sertoriana», en Los vascones de las fuentes antiguas, Javier Andreu Pintado (ed.); Col.lecció Instrumenta, 32, pp. 169-190

BALDINGER, KURT (1958): La formación de los dominios lingüisticos en la Península Ibérica, Ed. Gredos

BILBAO, MARIE-VÉRONIQUE (2006): Pratiques funéraires au Premier age du Fer: Analyse comparative de part et d'autre des Pyrénées; Université Michel de Montaigne - Histoire (Travail d'étude et de recherche en vue de l'obtention d'un Master 2 d'archéologie sous la direction de F. Tassaux), année scolaire 2005-2006

BLOT, JACQUES (1990): «L'Age du Fer en Pays Basque de France», Munibe, 42, pp. 181-187

BOURDONCLE, S.; GUILLOT, F.; LASNIER, T.; TEISSEIRE, H. (2006): «La vallée de la Bellongue au Moyen Âge (Pyrenees-Couserans)», Revue de Comminges et des Pyrénées Centrales. Saint-Gaudens. 122:2, pp. 173-208.

BROCA, PAUL (1875): Sur l'origine et la répartition de la langue Basque. Paris: Ernest Leroux

CASTAING, A. (1885): Les Origines des Aquitains: ethnogénie de l'Aquitaine primitive, Mémoires de la Societé d'Ethnographie

COFFYN, ANDRÉ (1986): «Recherches sur les Aquitains», Revue des Études Anciennes, 88:41-61.

COLLINS, ROGER (1992): "The Vaccaei, the Vaceti, and the rise of Vasconia», Law, Culture and Regionalism in Early Medieval Spain

COMBAS, LOÍS (2002): Diccionari General Occitan Cantalausa; Edicions Cultura d'Òc

COROMINES, JOAN (1973): «Du nouveau sur la toponymie occitane: Recherches sur les noms de lieux préromans de Languedoc et de Gascogne», Beiträge zur Namenforschung, vol. VIII, núm. 3-4, pp. 193-308.

CURCHIN, LEONARD A. (2008): «Place-names of the Ebro Valley: their linguistic origins», Palaeohispanica 8, pp. 13-33

DAUZAT, ALBERT \& ROSTAING, CHARLES: (1963): Dictionnaire des noms de lieux en France, Larousse 
DELAMARRE, XAVIER (2003): Dictionnaire de la langue gauloise, Paris: Errance

DOTTIN, GEORGES (1920): La langue gauloise. grammaire, textes et glossaire, C. Klincksieck

ESCUDE-QUILLET, JEAN-MARIE \& MAISSANT, CATHERINE (1996): L'Ariège, Carte archéologique de la Gaule

ESTORNÉS LASA, BERNARDO ET AL. (1998): Diccionario Auñamendi EspañolVasco, Ed. Auñamendi Argitaldaria

FABRE, GEORGES (2006): «Les peuples de l'Aquitaine au Second Âge du Fer»; en 25 ans d'archéologie en Béarn et en Bigorre, 1979-2004. De la Préhistoire à la fin de l'Antiquité. Fédération Archéologique des Pyrénées Occidentales et des Landes. Narrosse, p. 59-65

GARCÍA Y BELLIDO, ANTONIO (1955): «Hispanos no sul de França», Revista de Guimarães 65. 3-4, pp. 331-340

GARCÍA JIMÉNEZ, GUSTAVO (2006): «Las primeras producciones de antenas de la meseta. Patrones de influencia y desarrollo morfológico de las espadas de tipo Echauri/Quesada II», Gladius XXVI, pp. 19-60

GARDES, PHILIPPE (2001): »Habitat, territoires et évolution sociale en Aquitaine durant le dernier millénaire av. J.-C.», en Entre Celtas e iberos : las poblaciones protohistóricas de las Galias e Hispania (coord. por Luís Berrocal Rangel y Philippe Gardes), pp. 115-135

GORROCHATEGUI CHURRUCA, JOAQUÍN:

- (1984): Onomástica indígena de Aquitania; Bilbao: Universidad del País Vasco

- (1985): «Lengua aquitana y lengua gala en la Aquitania etnográfica», en Symbolae Ludovico septuagenario Mitxelena oblatae, J.L. Melena (ed.), Instituto de Ciencias de la Antigüedad, pp. 613-628

- (1989): «Indígenas y romanos en Aquitania a través de la epigrafía», Revista Internacional de Estudios Vascos 34:1, pp.16-30

- (1995): «Algunos Aspectos de la Onomástica Personal Antigua de los Pirineos», Muntanyes $i$ població. El passat dels Pirineus des d'una perspectiva multidisciplinària, Bertranpetit, J. y Vives, E. (eds.), pp. 151-156

- (2000): «Ptolemy's Aquitania and the Ebro Valley», en: Ptolemy: Towards a linguistic atlas of the earliest place-names of Europe, D. Parsons \& P. SimsWilliams (eds.).

- (2002): «Lenguas de los Pirineos en la antigüedad», Els Substrats de la Llengua Catalana (Treballs de la Societat Catalana de Llengua i Literatura, 1 - IEC), pp. 75 101

- (2005): «Establishment and analysis of Celtic toponyms in Aquitania and the Pyrenees», en J. de Hoz, ER Luján y P. Simms-Williams (eds.), New approaches to Celtic place-names in Ptolemy's Geography, pp. 153-188

GOYHENETCHE, MANEX (2000): Histoire Générale du Pays Basque (Tome 1), Ed. Elkartelan

GROSCLAUDE, MICHEL (2000): 70 Clés pour la formation de l'occitan de Gascogne. Per Noste / La Civada

GRZEGA, JOACHIM (2001): Romania Gallica Cisalpina, etymologisch-geolinguistische 


\section{El aquitano como lengua céltica (o vascones en Aquitania)}

Studien zu den oberitalienisch-raetoromanischen Keltizismen, Tübingen: Ed. M. Niemeyer

HUALDE, JOSÉ IGNACIO; LAKARRA, JOSEBA A.; TRASK, LARRY (1995): Towards a History of the Basque Language, John Benjamins Publishing co.

IGLESIAS, HECTOR (2009): «Sur l'origine présumée du fractionnement dialectal de la langue basque», ARSE Boletín anual arqueológico saguntino, 43 , pp. 1-24

IRIGOYEN ECHEVARRIA, A. (1987): «Cuestiones de toponimia vasca circumpirenaica», Cierbide Martinena, R., ed. - Pirenaico navarro--aragonés, gascón y euskera: V Cursos de Verano en San Sebastián., Universidad del País Vasco, pp. 71- 156

KRUTA, V. (2000): Les Celtes - Histoire et dictionnaire, Laffont

LARTIGUE, PHILIPPE (2004): Le vocalisme du gascon maritime dit gascon 'noir'; tesis dirigida por Patrick Sauzet, Univ. De Toulouse - Le Mirail

LEMOINE, JACQUES (1975): Toponymie du Languedoc et de la Gascogne, Paris, Picard

LIZOP, RAYMOND (1931): Histoire de deux cités Gallo-Romaines. Les Convenae et les Consorani. (Comminges et Couserans). Toulouse, Privat. Paris, Didier.

LÓPEZ, JOAN \& PONS, ENRIQUETA (1995): «Les necròpolis d'incineració tumulària de la zona pirinenca», El poblamiento antiguo de los Pirineos desde el punto de vista lingüístico - Muntanyes i població. El passat dels Pirineus des d'una perspectiva multidisciplinària, Bertranpetit, J. y Vives, E. (eds.), pp. 271-299

LUCHAIRE, A. (1876-1877): «Les origines linguistiques de l'Aquitaine », Bulletin de la Société des Sciences Lettres et Arts de Pau, pp. 349-423.

MASSOURRE, JEAN-LOUIS (2005): Le Gascon, Lengatge Estranh; Le luy de France: langues et civilisations romanes

MATASOVIC, RANKO (2009): Etymological Dictionary of Proto-Celtic, Brill, Leiden Indoeuropean Etymological Dictionary Series, 9

MORENO RESANO, ESTEBAN (2009): «Los Vascones en la Literatura Latina tardía (siglos IV-VII)», en Los vascones de las fuentes antiguas, Javier Andreu Pintado (ed.); Col.lecció Instrumenta, 32, pp. 261-290

MORVAN, MICHEL (2004): Noms de lieux du Pays basque et de Gascogne, Bonneton MUSSOT-GOULARD, RENÉE:

- (1996): Histoire de la Gascogne, P.U.F.

- (1997): «Wascones in plana descendunt... Civitas Lapurdum...», Lapurdum, 2 [mis en ligne le 01 septembre 2010, consulté le 21 février 2011]

ORPUSTAN, JEAN-BAPTISTE (2004): Nouvelle toponymie basque, en prensa

PEÑALVER IRIBARREN, XABIER (2001): El Bronce Final y la Edad del Hierro en la Euskal Herria Atlántica: Cromlechs y Castros, Complutum, 12, pp. 51-71

PEPIN, GUILHEM:

- (2005a): «Les Aquitains et les Gascons au haut Moyen Âge : genèse de deux peuples (1ère partie)». Bulletin de la Société Borda, 1er trim., 3-22

- (2005b): «Les Aquitains et les Gascons au haut Moyen Âge : l'affirmation des deux peuples (2e partie)». Bulletin de la Société Borda, 3e trim., 321-340

PINA POLO, FRANCISCO: 


\section{Nouvelle Revue d'Onomastique $n^{\circ} 54-2012$}

- (2004): «Deportaciones como castigo e instrumento de colonización durante la República Romana. El caso de Hispania», Vivir en tierra extraña, Francisco Marco Simón, Francisco Pina Polo, José Remesal Rodríguez eds., pp. 211-246

- (2006): «Calagurris contra Roma: de Acidino a Sertorio», Kalakorikos, 11, pp. 117-129

- (2009): «Sertorio, Pompeyo y el supuesto alineamiento de los vascones con Roma», en Los vascones de las fuentes antiguas, Javier Andreu Pintado (ed.); Col.lecció Instrumenta, 32, pp. 195-214

PINA, FRANCISCO \& ALFAYÉ, SILVIA (2002): «Propuesta de ubicación de los Volcianos en el área pirenaica», Palaeohispanica, 2

RICO, CHRISTIAN (1997): Pyrénées romaines - Essai sur un pays de frontière (IIIe siècle av. J. C. - IVe A. P.), Biblioteca de la Casa Velázquez, 14

ROHLFS, GERHARD (1977): Le Gascon, études de philologie pyreneenne; Tübingen / Niemeyer

ROMAN, YVES (1994): «Les Celtes, les sources antiques et la Garonne», Aquitania 12: 213-219

RUIZ ZAPATERO, GONZALO (1995): «El poblamiento del primer milenio a.C. en los Pirineos», El poblamiento antiguo de los Pirineos desde el punto de vista lingüístico - Muntanyes i població. El passat dels Pirineus des d'una perspectiva multidisciplinària, Bertranpetit, J. y Vives, E. (eds.), pp. 85-106

SAROÏHANDY, J. (1913): «Vestiges de phónetique ibérienne en territoire roman», Revista Internacional de Estudios Vascos, 7, pp. 475-497

SAYAS ABENGOCHEA, JUAN JOSÉ (1999): «De vascones a romanos para volver a ser vascones», Revista Internacional de Estudios Vascos, 44-1, pp. 147-184

SCHULTEN, ADOLF (1927): «Las referencias sobre los vascones hasta el año 810 después de d.C.», Revista Internacional de Estudios Vascos, 18, pp. 225-240

VIDAL, JOAN C. (2009): Los vínculos europeos del substrato íbero, La Busca edicions

VILLAR, FRANCISCO (1999): «Hispanocelta o celtibérico», en Language. Change and Typological Variation, E. C. Polomé \& C. F. Justus (eds.), pp. 60-77

Véase también:

Epigraphische Datenbank Clauss-Slaby En 19-11-2009 (contiene el CIL, Corpus Inscriptionum Latinarum) $<$ www.manfredclauss.de $>$

L'antiquité grecque et latine. En 12-11-2009. Dirigido por Philippe Remacle, Philippe Renault, François-Dominique Fournier, J. P. Murcia, Thierry Vebr y Caroline Carrat. (textos de autores clásicos como Estrabón, Ptolomeo, Plinio, o Julio César

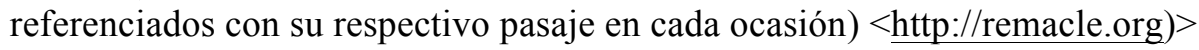




\section{El aquitano como lengua céltica (o vascones en Aquitania)}

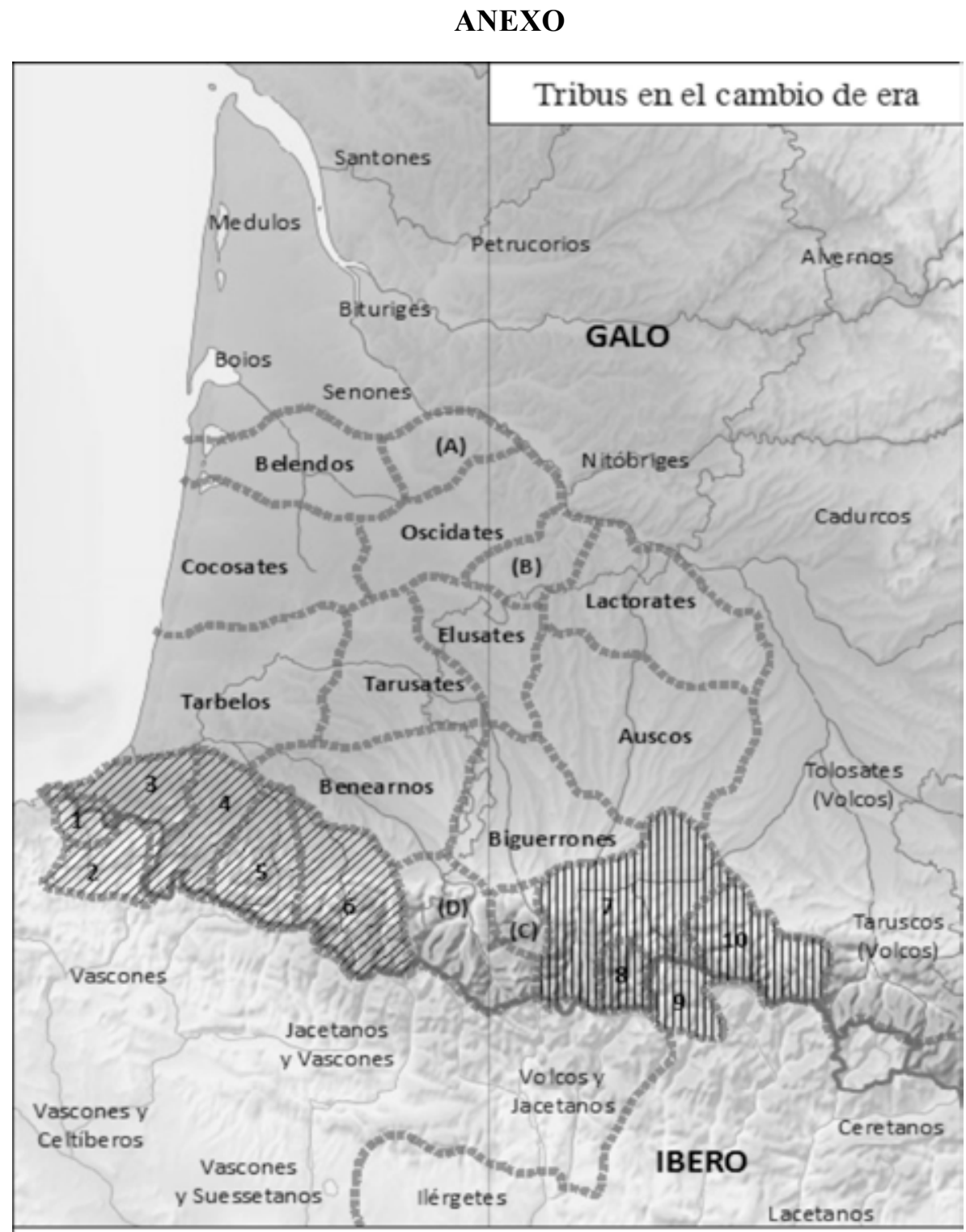

Tribus aquitanas en negrita; (A) Vasates, (B) Sotiates, (C) Crebennos, (D) Lassunos. Zonas de bilingüismo aquitano/vascón con trazo diagonal: 1Pinpedunos, 2-Vellates, 3-Lapurdos, 4-Bercorates, 5-Sibulates, 6-llurenses; zonas multilingües (vascón, volco, hispanocelta) con trazo vertical: $7^{*}$ Convenianos, 8-Onobrisates, 9-Garumnos, 10-Consoranos.

Figura núm. 1 - Extensión aproximada de las tribus aquitanas (las zonas 7,8,9,10 podrían tener un substrato aquitano celta); límites aproximados levantados según la distancia media entre centros tribales, se debe tener en cuenta que se desconoce la situación de sediboniates, tornates, garites y succasos. 